\title{
Provenance analysis of the Paleozoic sequences of the northern Gondwana margin in NW Iberia: Passive margin to Variscan collision and orocline development
}

\author{
Daniel Pastor-Galán ${ }^{\mathrm{a}}$ *, Gabriel Gutiérrez-Alonso a , J. Brendan Murphy ${ }^{\mathrm{b}}$, Javier Fernández-Suárez ${ }^{\mathrm{c}}$, \\ Mandy Hofmann ${ }^{\mathrm{d}}$, Ulf Linnemann ${ }^{\mathrm{d}}$ \\ ${ }^{\text {a }}$ Departamento de Geología, Universidad de Salamanca, Facultad de Ciencias, 37008, Salamanca, Spain \\ ${ }^{\mathrm{b}}$ Department of Earth Sciences, St. Francis Xavier University, Antigonish, Nova Scotia, Canada B2G 2 W5 \\ ${ }^{c}$ Departamento de Petrología y Geoquímica, Universidad Complutense and IGEO-CSIC, 28040 Madrid, Spain \\ d Senckenberg Naturhistorische Sammlungen Dresden, Königsbrücker Landstr. 159 (D-01109 Dresden), Germany
}

ABSTRACT

\begin{abstract}
The Cantabrian Zone of NW Iberia preserves a voluminous, almost continuous, sedimentary sequence that ranges from Neoproterozoic to Early Permian in age. Its tectonic setting is controversial and recent hypotheses include (i) passive margin deposition along the northern margin of Gondwana or (ii) an active continental margin or (iii) a drifting ribbon continent. In this paper we present detrital zircon U-Pb laser ablation age data from 13 sam- ples taken in detrital rocks from the Cantabrian Zone sequence ranging from Early Silurian to Early Permian in depositional age. The obtained results, together with previously published detrital zircon ages from Ediacaran- Ordovician strata, allow a comprehensive analysis of changing provenance through time. Collectively, these data indicate that this portion of Iberia was part of the passive margin of Gondwana at least from Ordovician to Late Devonian times. Zircon populations in all samples show strong similarities with the Sahara Craton and with zircons found in Libya, suggesting that NW Iberia occupied a paleoposition close to those regions of present-day northern Africa during this time interval. Changes in provenance in the Late Devonian are attributed to the onset of the collision between Gondwana and Laurussia. Additionally, the Middle Carboniferous to Permian samples record populations consistent with the recycling of older sedimentary sequences and exhumation of the igneous rocks formed before and during the Variscan orogeny. Late-Devonian to Permian samples yield zircon populations that reflect topographic changes produced during the Variscan orogeny and development of the lithospheric scale oroclinal buckling.
\end{abstract}

\section{Introduction}

In recent years, the profusion of published U-Pb detrital zircon age populations from clastic sedimentary rocks has become a powerful tool to unravel the paleogeographic and tectonic evolution of the Earth (Bradley, 2011) and to examine processes such as exhumation rates and related changes in topography during major tectonic events (Lonergan and Johnson, 1998; Stewart et al., 2008; Nie et al., 2010; Weislogel et al., 2010). Several such provenance studies have focused on the Ediacaran to Ordovician sedimentary rocks from the NW Iberian Variscides (e.g. Fernandez-Suarez et al., 1999, 2000; FernándezSuárez et al., 2002; Gutierrez-Alonso et al., 2003; Catalan et al., 2004; Díez Fernández et al., 2010) in order to understand the evolution of the northern Gondwana margin during Ediacaran and early Paleozoic times. However, there are only scarce detrital zircon data (Martinez et al., 2008) from mid- to late Paleozoic clastic strata. During this crucial

\footnotetext{
* Correspondingauthor.

E-mail address: dpastorgalan@usal.es (D. Pastor-Galán).
}

time interval, dramatic changes in tectonic environment occurred in NW Iberia, from a passive margin to a collisional orogen followed by the Late Carboniferous development of a regional oroclinal struc- ture and potential lithospheric delamination, in response to the Carboniferous collision of Laurussia with Gondwana (Weil et al., 2001, 2010; Gutiérrez-Alonso et al., 2004). A detailed analysis of the detrital zircon populations in this time interval provides an opportunity to mon- itor changes in provenance during continental collision and oroclinal bending of the orogen.

In this paper we present detrital zircon ages from 13 samples from the Cantabrian Zone (CZ) of NW Iberia, in the foreland of the Variscan belt of NW Iberia whose depositional age spans the passive margin stage of northern Gondwana from Silurian to upper Devonian times, the con- tinental collision (Variscan orogeny) from upper Devonian to upper Carboniferous times and the development of the Cantabrian Orocline (CO) (Gutiérrez-Alonso et al., 2012) during the latest Carboniferous and the early Permian (Johnston and GutiérrezAlonso, 2010). The ob- jective of our study is threefold: (i) to characterize the sources of the sediments during its Silurian-Devonian passive margin stage in order to constrain its paleogeography; (ii) to provide constraints on the 
exhumation and erosion of the different units involved in the Variscan orogenic event; and (iii) to account for the provenance changes related with the formation of the $\mathrm{CO}$ as well as the potentially major topographic changes triggered by the hypothesized lithospheric detachment event. In addition, by comparing the SilurianDevonian data with previously pub- lished data for the Ediacaran-Ordovician, changes in provenance during the evolution of the passive margin can be assessed.

\section{Generalgeology}

\subsection{Regional setting}

In the Late Neoproterozoic and Early Cambrian, a long history of subduction and accretion of island arcs occurred along the northern margin of Gondwana (Murphy et al., 2000; Linnemann et al., 2008; Nance and Linnemann, 2008; Pereira et al., 2012). After the protracted pe- riod of rifting (Sanchez-Garcia et al., 2008; Pereira et al., 2012), the Rheic Ocean opened by the Late Cambrian-Early Ordovician with the separation of several peri-Gondwanan terranes (Avalonia, Carolina, Ganderia) from the northern margin of Gondwana (Murphy et al., 2006; Nance et al., 2010). This period of rifting and early drifting is recorded in NW Iberia by widespread rift-related igneous activity (Díez-Montes, 2006; Valverde-Vaquero et al., 2006; Gutiérrez-Alonso et al., 2007; Murphy et al., 2008), and by the coeval accumulation of a thick passive margin sequence (e.g. Aramburu et al., 2002). The Rheic Ocean reached its greatest width (ca. $4000 \mathrm{~km}$ ) during the Silurian (Nance et al., 2010 and references therein).

Largely on the basis of paleomagnetic data, some authors interpret the location of NW Iberia during the Late Silurian to be part of drifting ribbon continent variously called Armorica or the Hun terrane (Van Der Voo, 1982, 1988; van der Voo, 1993; Tait et al., 1994; Tait, 1999; Stampfli and Borel, 2002). The drifting of this putative microcontinent away from Gondwana is held to be responsible for the opening of the Paleotethys Ocean and its collision against Laurentia to be responsible for the closure of the Rheic Ocean and the onset of Variscan orogenesis. Other authors, however, place NW Iberia along the northern Gondwana passive margin throughout the Paleozoic (Robardet, 2003; Linnemann et al., 2004, 2008; Barreiro et al., 2006; Fernandez-Suarez et al., 2006; Gutiérrez-Alonso et al., 2008; Martínez Catalán et al., 2009; Díez Fernández et al., 2010), implying that subduction of Rheic Ocean litho- sphere, which began in the Early Devonian was directed northward i.e. away from the Gondwanan margin.

In the latter scenario, the closure of the Rheic Ocean is recorded by the deformation associated with the final collision between Laurentia and Gondwana and in some ophiolitic suites preserved in the suture between these continents (e.g. Arenas et al., 2007). Continental collision began at ca. 365 Ma (Dallmeyer et al., 1997) and continued shortening is thought to have led the extensional collapse of the thickened hinterland at $320 \mathrm{Ma}$ (Arenas and Catalan, 2003; Martínez Catalán et al., 2009). The latter event is coeval with the development of the non-metamorphic foreland fold-thrust belt of Gondwana (e.g. Perez-Estaun et al., 1994), which is exposed only in the CZ of NW Iberia.

The $\mathrm{CO}$ was developed after closure of the Rheic Ocean and the development of the Variscan orogen. Gutiérrez-Alonso et al. (2004) pro- pose a thick-skinned model for oroclinal development which involves lithosphericscale rotation of the orogen limbs, with extension in the outer arc resulting in thinning of the mantle lithosphere, and coeval short- ening in the inner arc (Julivert and Marcos, 1973; Julivert and Arboleya, 1986; Alvarez-Marron and Perez-Estaun, 1988; Gutiérrez-Alonso et al., 2010; Pastor-Galán et al., 2012a). Lithosphere thickening beneath the inner arc would have resulted in gravitational instability causing detach- ment and removal of the mantle lithosphere from the lower crust, in turn resulting in upwelling of the asthenosphere thereby triggering voluminous Late Carboniferous-Permian magmatism in the Variscan fold-andthrust belt as a result of an associated increase in heat flow (FernandezSuarez et al., 2000; Gutiérrez-Alonso et al., 2004, 2011a,b; Fernández-Suárez et al., 2011). The hypothesized high heat flow may also explain (i) uncommon high coal ranks in the upper- most Carboniferous continental basins (Colmenero and Prado, 1993; Colmenero et al., 2008); (ii) gold mineralization in the foreland fold- and-thrust belt (Martin-Izard et al., 2000); (iii) remagnetization recorded in Late Carboniferous-Permian strata (Weil and Van der Voo, 2002); (iv) dolomitization along late breaching and out-ofsequence thrusts (Gasparrini et al., 2006) and (v) post-orogenic topographic elevation (Muñoz-Quijano and Gutiérrez-Alonso, 2007).

\subsection{Geology of the Cantabrian Zone}

The CZ of northern Iberia is situated in the core of the CO (Gutiérrez-Alonso et al., 2004; Weil, 2006) (Fig. 1A and B). The CZ is a classical foreland fold-and-thrust belt characterized by thin-skinned tec- tonics with a transport direction towards the core of the arc (Pérez- Estaún et al., 1988). Deformation in the CZ is characterized by low finite strain values (GutiérrezAlonso, 1996; Pastor-Galán et al., 2009), and cleavage is only locally developed. A very low-grade of metamor- phism is indicated by illite crystallinity (Gutierrez-Alonso and Nieto, 1996; Brime et al., 2001) and by conodont color alteration index studies (Bastida et al., 2004; García-López et al., 2007). The Variscan deforma- tion is diachronous towards the foreland. The first record of instability in the passive margin, due to its loading in the hinterland, is interpreted to have occurred in the upper Devonian (Keller et al., 2008) but the sedimentary record of a fore-bulge and a fore-deep is not evident until the Lower Carboniferous. Deformation began in the Late Mississippian (Dallmeyer et al., 1997) and resulted in the development of several clas- tic wedges related to the different thrust units.

The CZ consists of thick Neoproterozoic arc-related sequences, unconformably overlain by ca. $4500 \mathrm{~m}$ of lower Paleozoic clastic and carbonate platformal strata (Fig. 2) that thin towards the east and culminate with a distinctive sequence of Silurian black shale and iron-rich sandstone (Fig. 2). Paleocurrent data recorded in the lower paleozoic strata indicate that its sediment source was located to the east (Aramburu and García-Ramos, 1993; Shaw et al., 2012) but there are no currently exposed potential source rocks. In the CZ, the Devonian and Mississippian succession consists of alternating passive margin carbonate and siliciclastic formations (Fig. 2) where sev- eral transgressions and regressions have been documented (Aramburu et al., 2002; Gibbons and Moreno, 2002; Keller et al., 2008). This succes- sion is overlain conformably by a $5000 \mathrm{~m}$ thick Westphalian (Late MississippianEarly Pennsylvanian) syn-orogenic sequence dominated by shallow marine and interbedded continental clastic strata followed by unconformably overlying Stephanian (Upper Pennsylvanian) and Permian rocks.

Stephanian strata are younger westwards (e.g. Colmenero et al., 2008) and show little deformation. They are coal-bearing, continen- tal, clastic rocks including conglomerates, sandstones and pelities (Fig. 2) that show similar stratigraphic and sedimentological charac- teristics over much of northern Iberia. Given this similarity, it is pos- sible that the Stephanian succession was continuous across much of the western and southern portions of the CZ and the adjacent West Asturi- an Leonese Zone (Corrales, 1971). According to Pastor-Galán et al. (2011), these Stephanian rocks do not contain the characteristic Variscan joint pattern that is observed in the older rocks, suggesting de- position after the bulk of Variscan deformation had taken place.

Permian rocks were deposited in small basins (Martínez-García, 1991) that post-date the formation of the CO (Weil et al., 2010; Pastor-Galán et al., 2011). These strata are only moderately tilted and are not internally deformed. The dominant lithologies are conti- nental red conglomerates, red shales and sandstones, with minor limestones, volcaniclastic rocks and calcalkaline basaltic lava flows with sparse isolated coal seams (MartínezGarcía, 1981; Suárez, 1988). 


\section{U-Pb LA-ICP-MS geochronology}

\subsection{Sampling strategy}

Thirteen samples were collected in the CZ ranging in age from Early Silurianto Early Permian (Figs. 1B, 2 and 3). The location of each sample is given in Supplementary file S1. Four samples are from the pre-orogenic Silurian to Lower Pennsylvanian sequences: (1) two samples from the platform sequence (PG14; Lower Silurian, Formigoso Formation - sandstones and black shales and PG12; Upper Devonian Fueyo Formation - siltstones and sandstones); (2) one sample from the fore-deep succession (G4; MiddleUpper Mississippian Olleros Formation - a turbiditic clastic succession) and (3) one sample from the oldest clastic wedge in the CZ (PG9, Early Pennsylvanian (Namurian) San Emiliano Formation - sandstones with olitostromic limestones) that is coeval with the Variscan deformation progressing from the west (pres- ent day coordinates) (Dallmeyer et al., 1997).

We selected three samples in younger syn-orogenic foreland basin clastic wedge deposits of Westphalian age (Bashkirian-Moskovian).
These samples are PG5 (Lena Group, Westphalian A-C), PG4 and PG6 (Sama Group, Westphalian B-D) situated in the Central Coal Basin (CCB; Fig. 1B). The succession in the CCB is Westphalian A-D (Middle Pennsylvanian) in age and consists of a marine-dominated (mostly siliciclastic with limestone intercalations) lower section (Lena Group) and an upper section with more continental influence (Sama Group) characterized by thick deposits of sandstone, conglomerate and shale with abundant interbedded coal seams.

Additionally we selected four samples in continental coal bearing Stephanian clastic rocks to document the effects and after-effects of oroclinal development. One sample is from Stephanian A strata (PG1, ca. 307 Ma; Kasimovian according to the marine stages in Gradstein et al., 2004 and Heckel and Clayton, 2006) that crops out in the Esla unit (Alonso, 1987, 1989; Fig. 1B), and three samples (PG8, PG11 and PG7) are from Stephanian B-C (са. 305, 304 and 303 Ma, respectively, Kasimovian to Gzhelian; Fig. 1B) strata. The latter three samples uncon- formably overlie different rock units (Figs. 2 and 3). Sample PG8 was taken in a basin that generally overlies Devonian and Early Carboniferous rocks of the CZ whereas samples PG11 and PG7

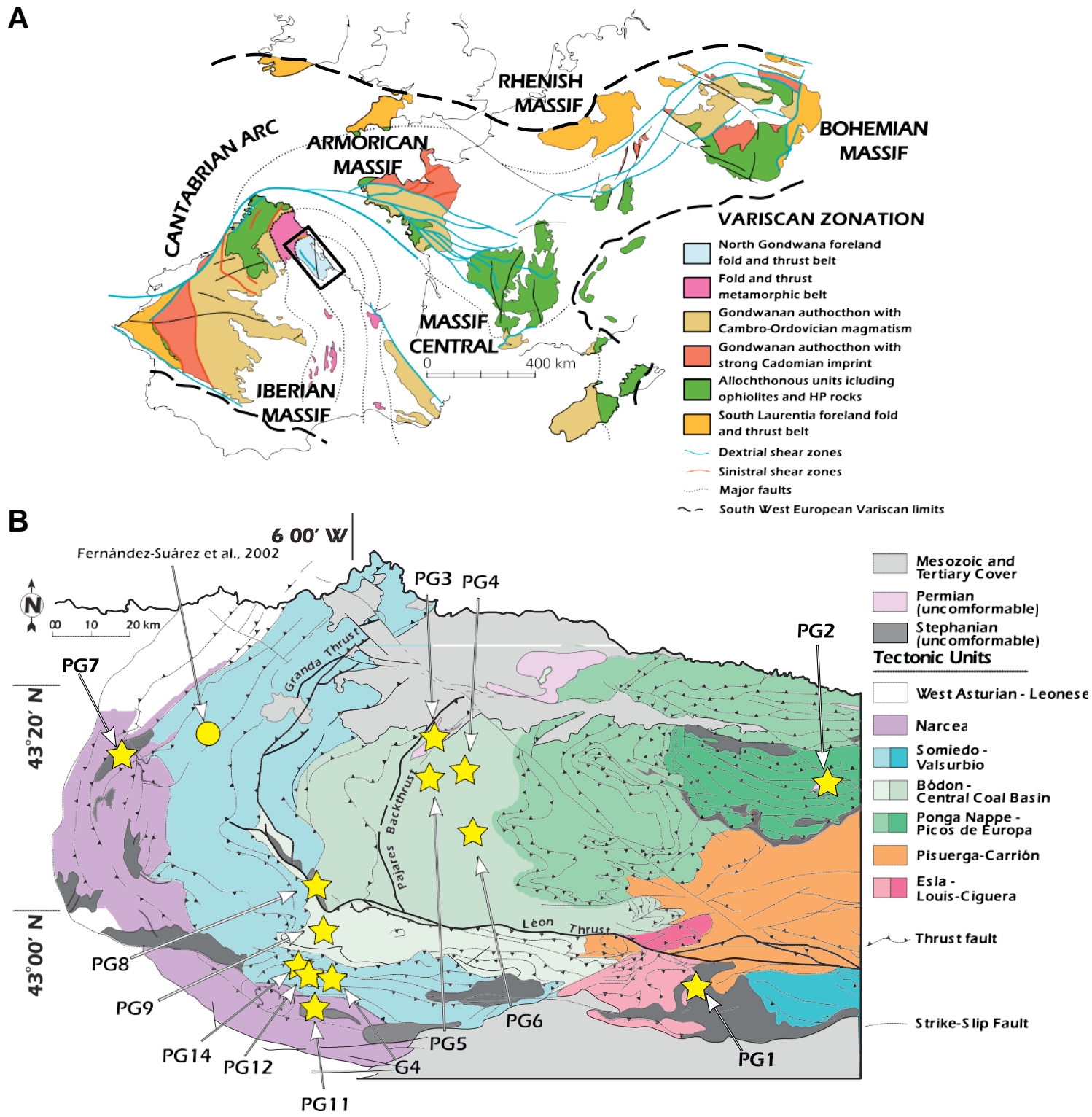

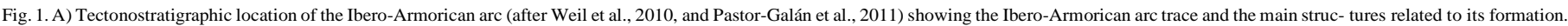
B) Cantabrian Zone zonation after Alonso et al. (2009) showing the main structures and sample situation. 


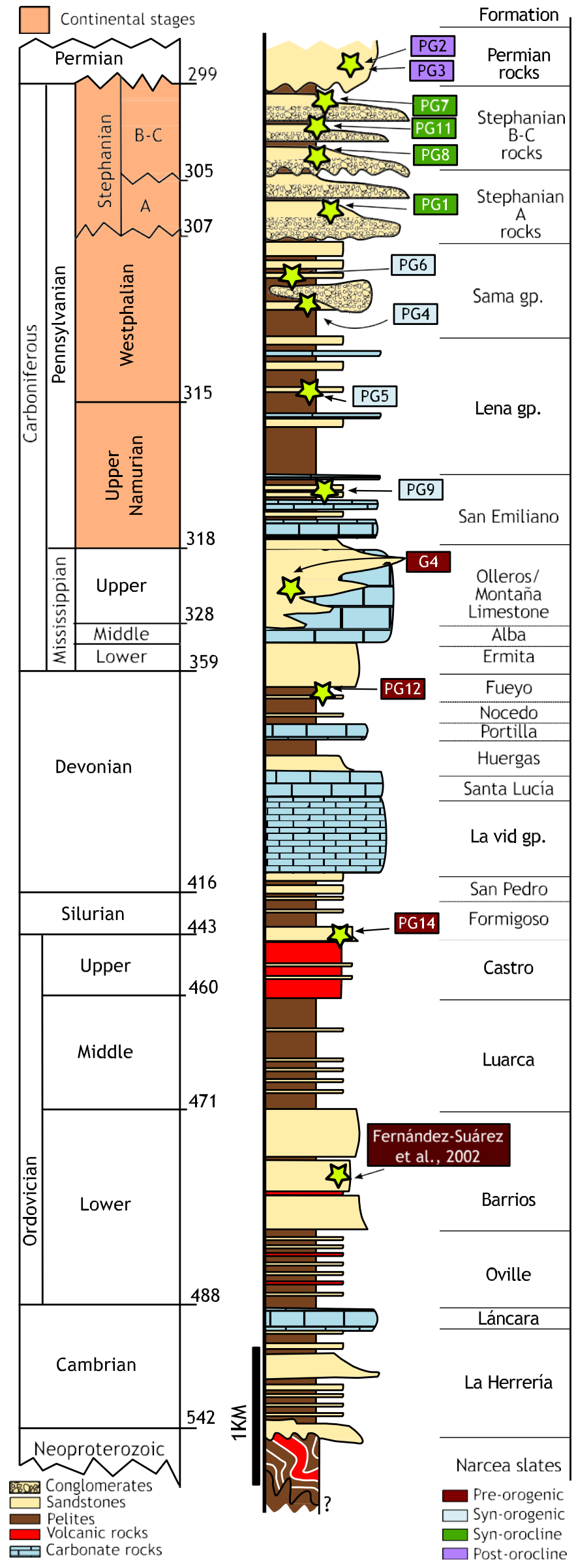

(Fig. 1B) were taken in basins which overlie Ediacaran-Cambrian strata of the Narcea Antiform.

Two samples were collected within the mostly siliciclastic with interbedded volcanics Permian succession (PG2 and PG3, Sotres Formation, ca. 292 and 295 Ma respectively). PG2 was taken in the easternmost sector of the CZ and PG3 in its central part (Figs. 1B, 2 and 3).

\subsection{Analytical method}

Approximately 120 detrital zircon grains from each sample were separated and extracted using facilities at Complutense (Madrid) and Salamanca universities, then mounted in epoxy resin with zircon stan- dards SL13 ( $U=238$ ppm) and TEMORA $\left({ }^{206} \mathrm{~Pb}^{*}{ }^{238} \mathrm{U}=0.06683\right)$. The polished mounts were photographed before the analysis to document each zircon analysis. Individual zircon grains were analyzed for $\mathrm{U}$, Th, and $\mathrm{Pb}$ isotopes by LA-ICP-MS (Laser Ablation with Inductively Coupled Plasma Mass Spectrometry) at the Museum für Mineralogie und Geologie (Senckenberg Naturhistorische Sammlungen Dresden), using a Thermo-Scientific Element 2 XR sector field ICPMS coupled to a New Wave UP-193 Excimer Laser System. A teardrop-shaped, low-volume laser cell was used to enable sequential sampling of heterogeneous grains (e.g. growth zones) during time-resolved data acquisition. Each analysis consisted of $15 \mathrm{~s}$ background acquisition followed by $35 \mathrm{~s}$ data acquisi- tion, using laserspot sizes of 15-35 $\mu \mathrm{m}$. A common-Pb correction based on the interference and background-corrected ${ }^{204} \mathrm{~Pb}$ signal and a model $\mathrm{Pb}$ composition (Stacey and Kramers, 1975) was carried out where neces- sary. The criterion for correction was whether the corrected ${ }^{207} \mathrm{~Pb} /{ }^{206} \mathrm{~Pb}$ lay outside the internal error of measured ratios. Time-resolved signals of the LA-ICP-MS were checked in order to detect disturbances caused by cracks or mineral inclusions. In such cases, analyses were excluded from age calculations. Raw data were corrected for background signals, common $\mathrm{Pb}$, laser-induced elemental fractionation, instrumental mass discrimination, and time-dependent elemental fractionation of $\mathrm{Pb} / \mathrm{Th}$ and $\mathrm{Pb} / \mathrm{U}$ using an Excel ${ }^{\circledR}$ spreadsheet program developed by A. Gerdes (Institute of Geosciences, Johann Wolfgang Goethe-University Frankfurt, Frankfurt am Main, Germany). Reported uncertainties were propagated by quadratic addition of the external reproducibility obtained from the standard zircon GJ-1 (ca. $0.6 \%$ and $0.5-$ $1 \%$ for the ${ }^{207} \mathrm{~Pb} /{ }^{206} \mathrm{~Pb}$ and ${ }^{206} \mathrm{~Pb} /{ }^{238} \mathrm{U}$ respectively) during individual analytical sessions and the within- run precision of each analysis. Analyses with a concordance in the range $90-110 \%$ were used for concordia and probability density distribution plots. A total of 1620 analyses were carried out on thirteen samples, of those, 216 were $>10 \%$ discordant and were discarded. Discordance may originate from $\mathrm{Pb}$ loss, addition of common $\mathrm{Pb}$ or ablation of different age domains within the zircon. Concordia diagrams and probability den- sity plots (Fig. 6) were produced using Isoplot/Ex 3.7 (Ludwig, 2001). For concordant analyses (i.e. analyses whose $2 \sigma$ error ellipse intercepts the concordia curve) we used concordia ages and errors (Ludwig, 1998) as calculated by Isoplot. For discordant analyses (still within the 90-110\% concordance range) older than $1000 \mathrm{Ma}$ we use the more precise ${ }^{207} \mathrm{~Pb} /{ }^{206} \mathrm{~Pb}$ age. Further details on analytical protocol and data processing may be found in Frei and Gerdes (2009).

\subsection{Statistical treatment}

In addition to the probability density plots in this study we have used a Kernel density estimation (Vermeesch, 2012). Kernel density estimation was used to produce a graph that visually groups statisti- cally similar samples (Sircombe and Hazelton, 2004) in order to mea- sure the similarity of the different samples analyzed. In addition, if the analyzed samples are similar it is a useful technique to recognize the main zircon-forming events that are recorded by the studied rocks.

Fig. 2. Idealized stratigraphic column of the Cantabrian Zone showing the stratigraphic position of the samples selected for this study. 

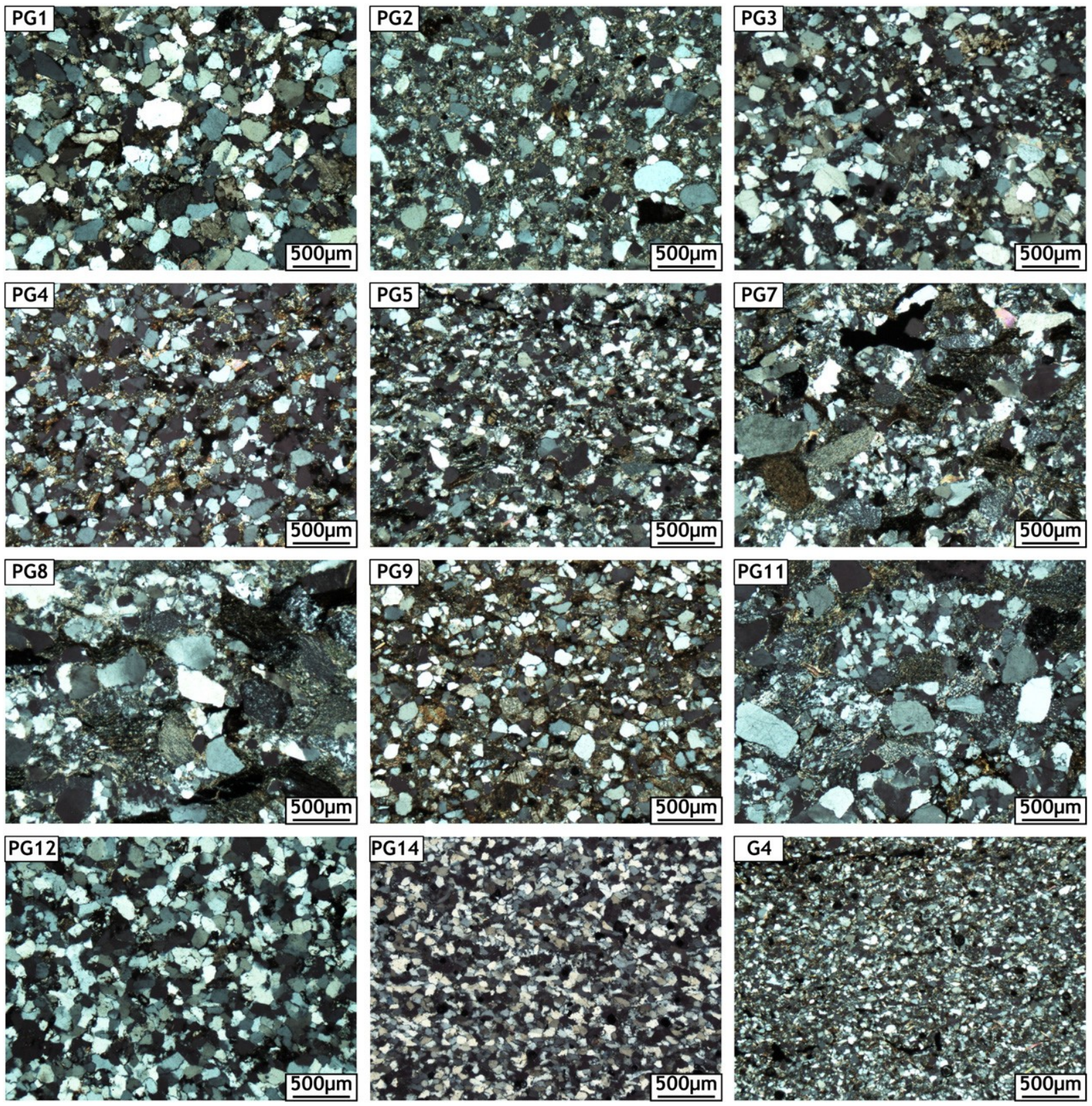

Fig. 3. Thin section microphotographs from the studied samples.

The kernel density function approximates the shape of the zircon prob- ability density curves at a particular age by taking into account the age uncertainties and the influence of estimated ages within close proxim- ity of a given age. The average distance between the smoothed probabil- ity curves is then employed as a measure of dissimilarity, and displayed on a graph. This approach can provide a statistical means for assessing the extent of those similarities.

\section{Results}

The U-Pb data are given in Tables DR1 to DR13 of the supplementary data and are represented in the concordia plots (Figs. 4 and 5) and the relative probability plots (Figs. 6 and 7). Additionally, we have plotted all U-Pb age data from the 13 samples in a kernel density plot (Wand and Jones, 1995) using a smoothing wavelength of $15 \mathrm{Ma}$ (Fig. 8). The peaks in this plot are used to identify the age/span of the main episodes of zircon-forming events recorded in the detrital population of the stud- ied samples. As the data from the pre-orogenic rocks provide the background necessary to interpret the data from the syn-orogenic and postorogenic rocks, we discuss the data in the order of their deposi- tional age, from oldest to youngest (Fig. 2).

\subsection{Pre-orogenic sequence (Silurian - PG14, Devonian - PG12, Carboniferous - G4, PG9)}

In the Silurian sample (PG14, Fig. 2), about 30\% of the zircons represent the youngest population and range from 850 to $540 \mathrm{Ma}$. Comparable populations, ca. 30\% each, yield 1150-900 Ma and 2150-1750 Ma ages. Additionally, 9\% of the zircons define an Archean population (2800-2500 Ma; Figs. 6 and 8). Younger pre-orogenic samples (Devonian and Carboniferous: PG12, G4 and PG9) are characterized by a higher proportion (39\%-46\%) of 850-540 Ma zircons. In sample PG-12 (Devonian), this is also the youngest population (Figs. 3 and 5). The zircons with ages ranging between 1150 and $900 \mathrm{Ma}$ are the second most abundant population ( $26 \%$ to $32 \%$ ) in all three samples. This population is more abundant than in the syn-orogenic and post-orogenic rocks 


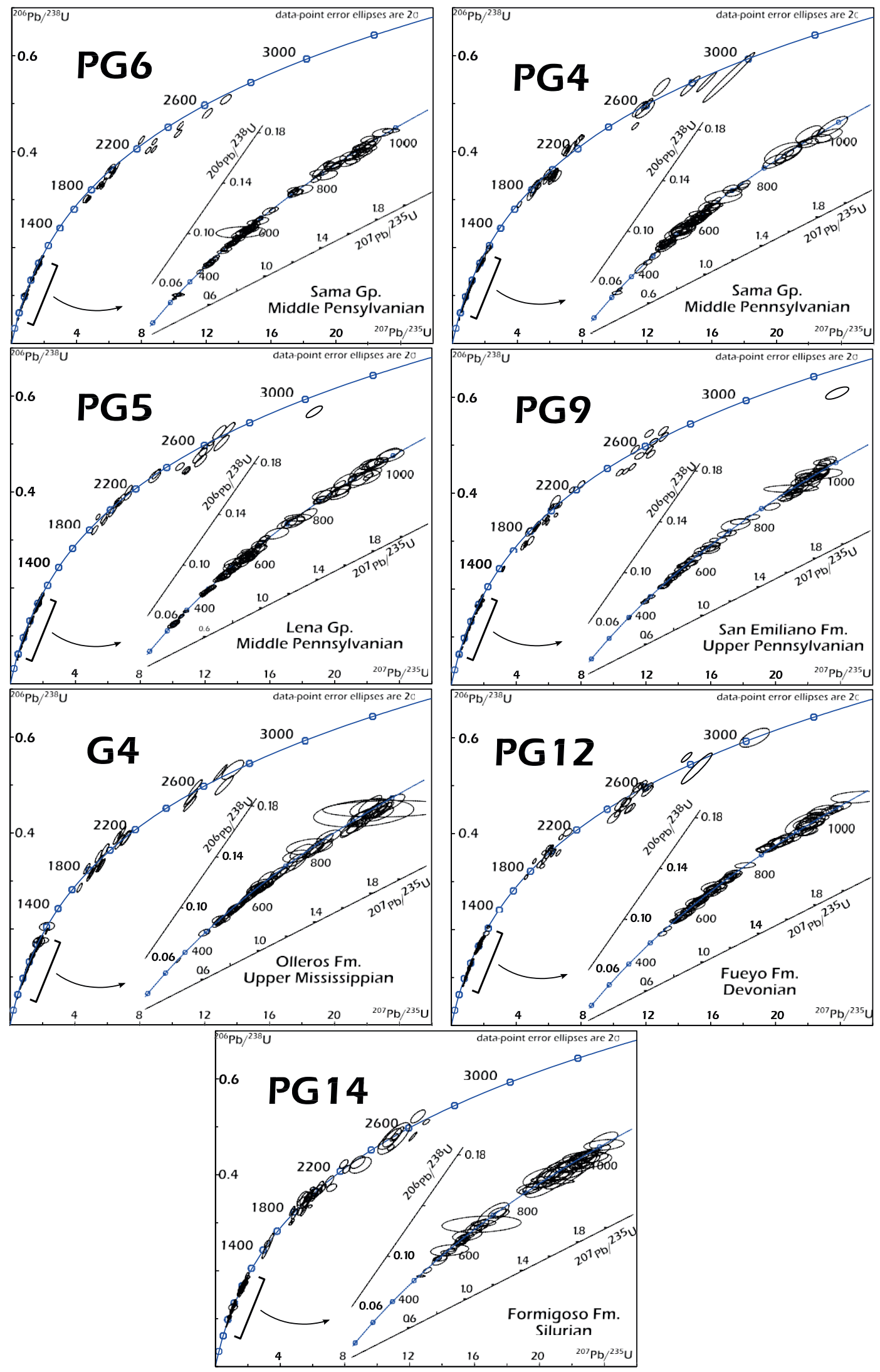

Fig. 4. U-Pb concordia plots. Samples are chronologically ordered from Silurian to Middle Pennsylvanian. Ellipses represent $2 \sigma$ uncertainties.

(Figs. 6-8). Older Proterozoic zircons represent a comparatively smaller proportion (11 and 21\% respectively) whereas the 2800-2500 Ma zircons range between $7 \%$ and $14 \%$. In addition, G4 and PG9 contain a small proportion of Late Cambrian-Early Ordovician (510-475 Ma; 1\% and 3\% respectively) and Mississippian (360-320 Ma; $1 \%$ both samples) zircons, the latter representing the youngest population in both samples. 

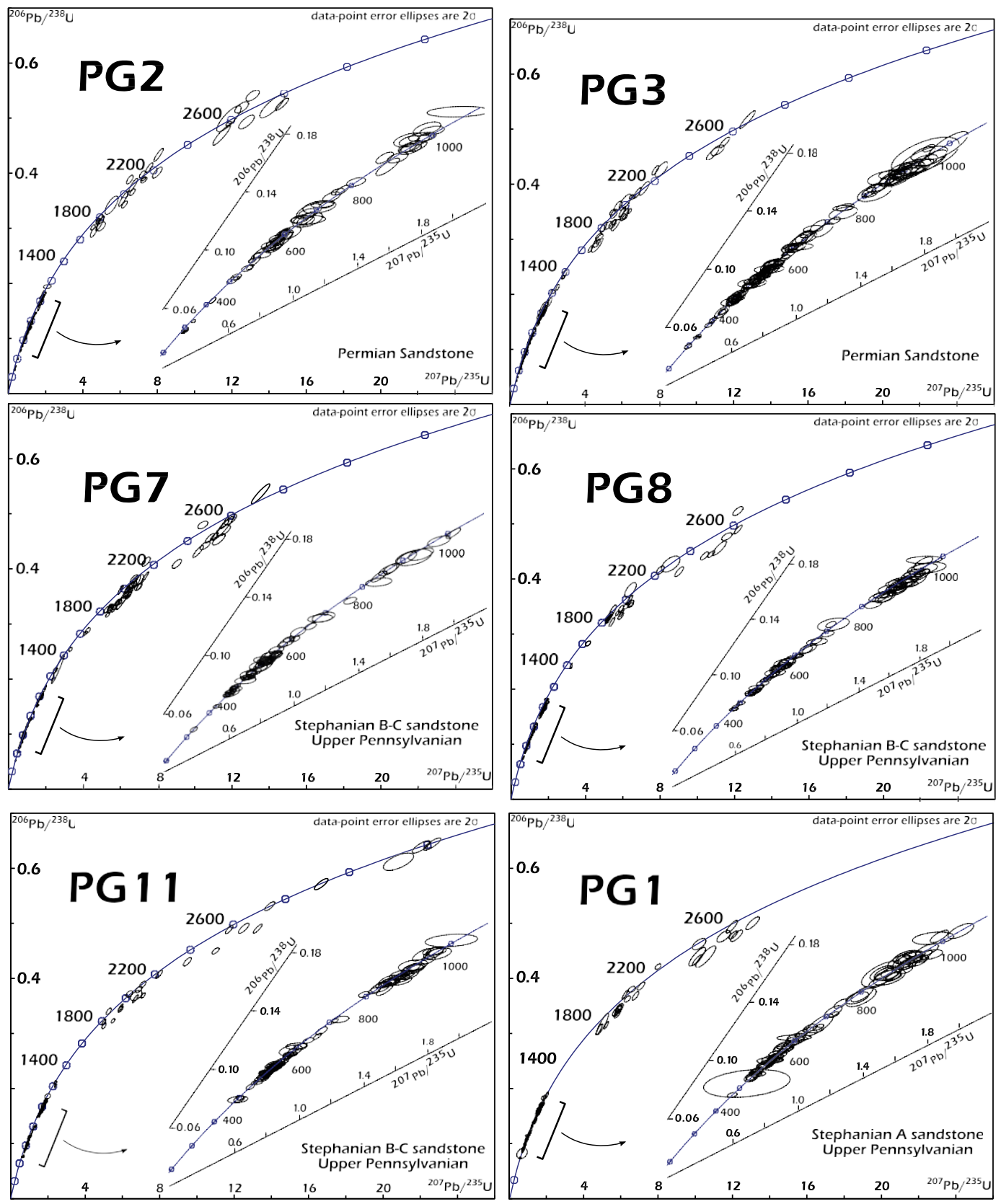

Fig. 5. U-Pb concordia plots. Samples are chronologically ordered from Upper Pennsylvanian to Early Permian. Ellipses represent $2 \sigma$ uncertainties.

The youngest zircons in samples Silurian (PG-14) and Devonian (PG-12) are $523 \mathrm{Ma}$ and $544 \mathrm{Ma}$, respectively, both much older than their depositional age as established by their fossil content (Bastida, 2004 and references therein). In the Mississippian sample (G4), however, the youngest zircon (365 Ma) is similar to its depositional age. The youngest zircon in sample PG9 is $402 \mathrm{Ma}$ (see tables in supplementary material).

\subsection{Syn-orogenic sequence (Lower and Middle Pennsylvanian - PG5, PG4 and PG6)}

The syn-orogenic samples (Figs. 4, 6, and 9) are dominated by an 850-540 Ma population (40\%-52\%). The second most abundant pop- ulation in samples PG5 and PG6 is between 1150 and $900 \mathrm{Ma}(21 \%$ - 24\% respectively) whereas in PG4, this population only represents $12 \%$. In the three samples, a Paleoproterozoic (2150-1750 Ma) pop- ulation represents $10 \%-20 \%$ of the analyses and an Archean population
(2800-2500 Ma) represents 5\%-8\% of the analyses. The three samples contain between $3 \%$ and $8 \%$ of zircons in the Cambrian- Ordovician (510-475 Ma) and Mississippian (360-320 Ma) age in- tervals respectively.

The youngest zircons in samples PG5, PG4 and PG6 are 326, 325 and 322 Ma respectively (Serpukhovian), 7-11 m.y. older than the depositional ages established by their fossil content (see tables in supplementary material).

\subsection{Syn-oroclinal sequence $P G 1, P G 8, P G 11$ and $P G 7$}

In three of the samples from post-orogenic but syn-oroclinal strata (PG1, PG8, PG11; Figs. 5, 7 and 9) the main age populations are 850-540 Ma (41\%-48\%), $1150-900$ Ма (27\%-30\%), 2150-1750 Ма

(13\%-21\%) and 2800-2500 Ma (6\%-9\%). These samples contain few zircons with 510-475 Ma age population (Cambrian-Ordovician) (b 4\%) and no 360-320 Ma zircons (Mississippian). The youngest zircons in 


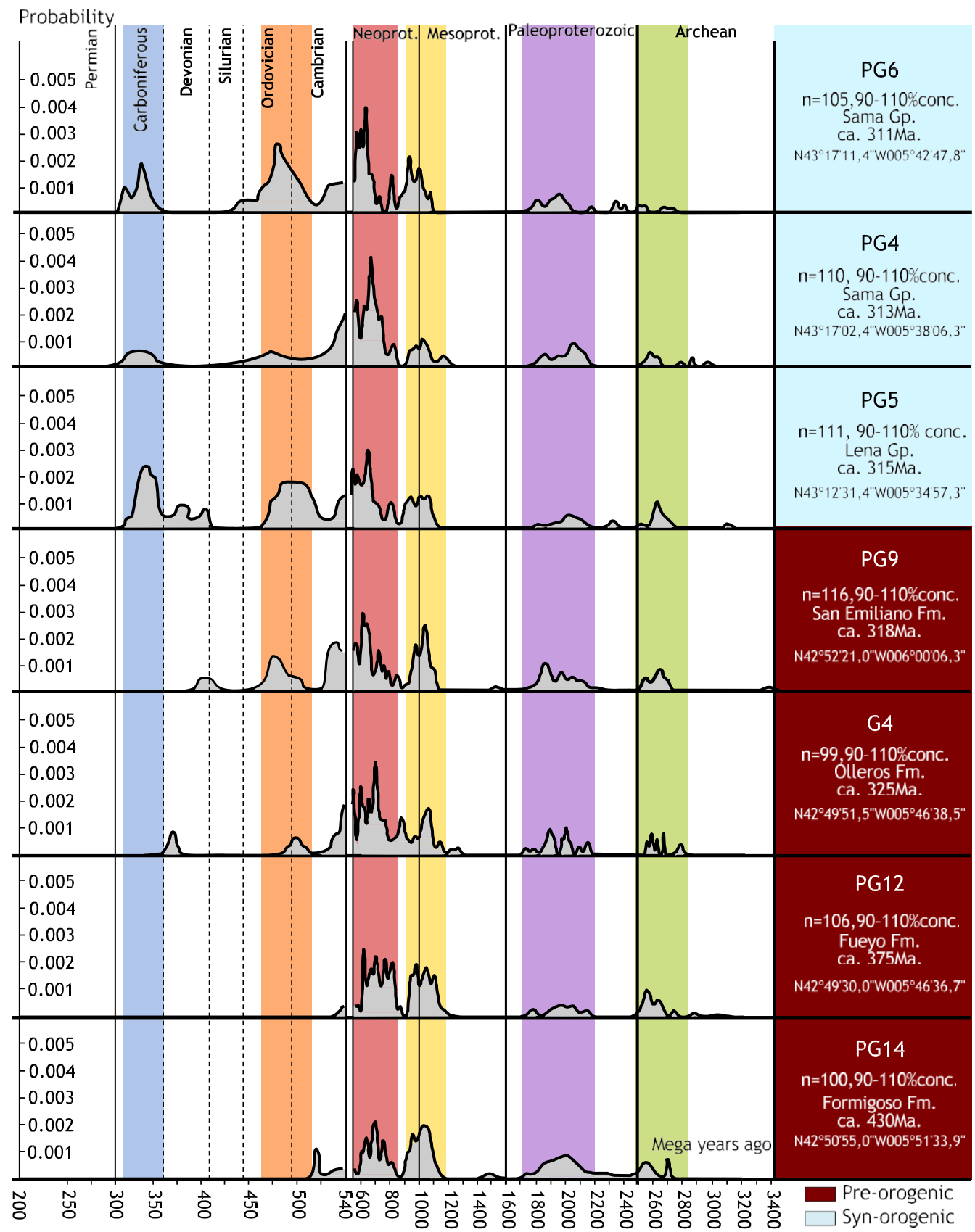

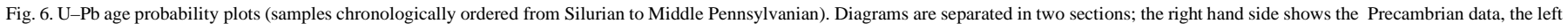
hand side shows the Paleozoic data. Periods are differentiated by colors. At both sides the populations described in the text are limited by dashed lines.

these samples are $481 \mathrm{Ma}, 494 \mathrm{Ma}$ and 474 Ma respectively, i.e. signifi- cantly older than their respective depositional ages.

Sample PG7 has few Mississippian zircons (youngest at $335 \mathrm{Ma}$ ) and a slightly higher proportion of Cambrian-Ordovician (510-475 Ma) zir- cons (8\%). Other populations present are similar to those of the other three samples but occur in different proportions (850-540 Ma, 30\%; 1150-900 Мa, 9\%; 2150-1750 Мa, 29\%; and 2800-2500 Ma, 10\%).

\subsection{Permian sequence (PG2 and PG3)}

Permian samples contain Proterozoic (850-540 Ma, 41\%; 1150900 Ma, 20\%-25\%; 2150-1750 Ma, 11-20\%; and 2800-2500 Ma, 2-7\%) and Paleozoic populations (510-475 Ma 2-10\%; 360-320 Ma, 2-5\%; 310-290 Ma, 1-10\%). The youngest zircons (298 Ma in PG3, $290 \mathrm{Ma}$ in PG2) in both samples are approximately the same age as the estimat- ed depositional age of the rocks (ca. $295 \mathrm{Ma}$ ).

\subsection{Main zircon-forming events}

With the Kernel density function and using a wavelength of 15 m.y., seven populations can be distinguished in the whole detrital zircon pop- ulation of the 13 samples analyzed (Fig. 8): (1) an Archean population (2800-2500 Ma) with a maximum at $2615 \mathrm{Ma}$; (2) a 2150-1750 Ma,

with two maxima at 2000 and $1875 \mathrm{Ma}$; (3) a 1150 to 900 Ma population with a maximum at $1025 \mathrm{Ma}$; (4) an 850-540 Ma population with a maximum at 630 Ma; (5) a Late Cambrian to Early Ordovician pop- ulation (510-475 Ma) with a maximum at $495 \mathrm{Ma}$; (6) a Mississippian population (360 to $320 \mathrm{Ma}$ ) with a maximum at $338 \mathrm{Ma}$ and a Late 


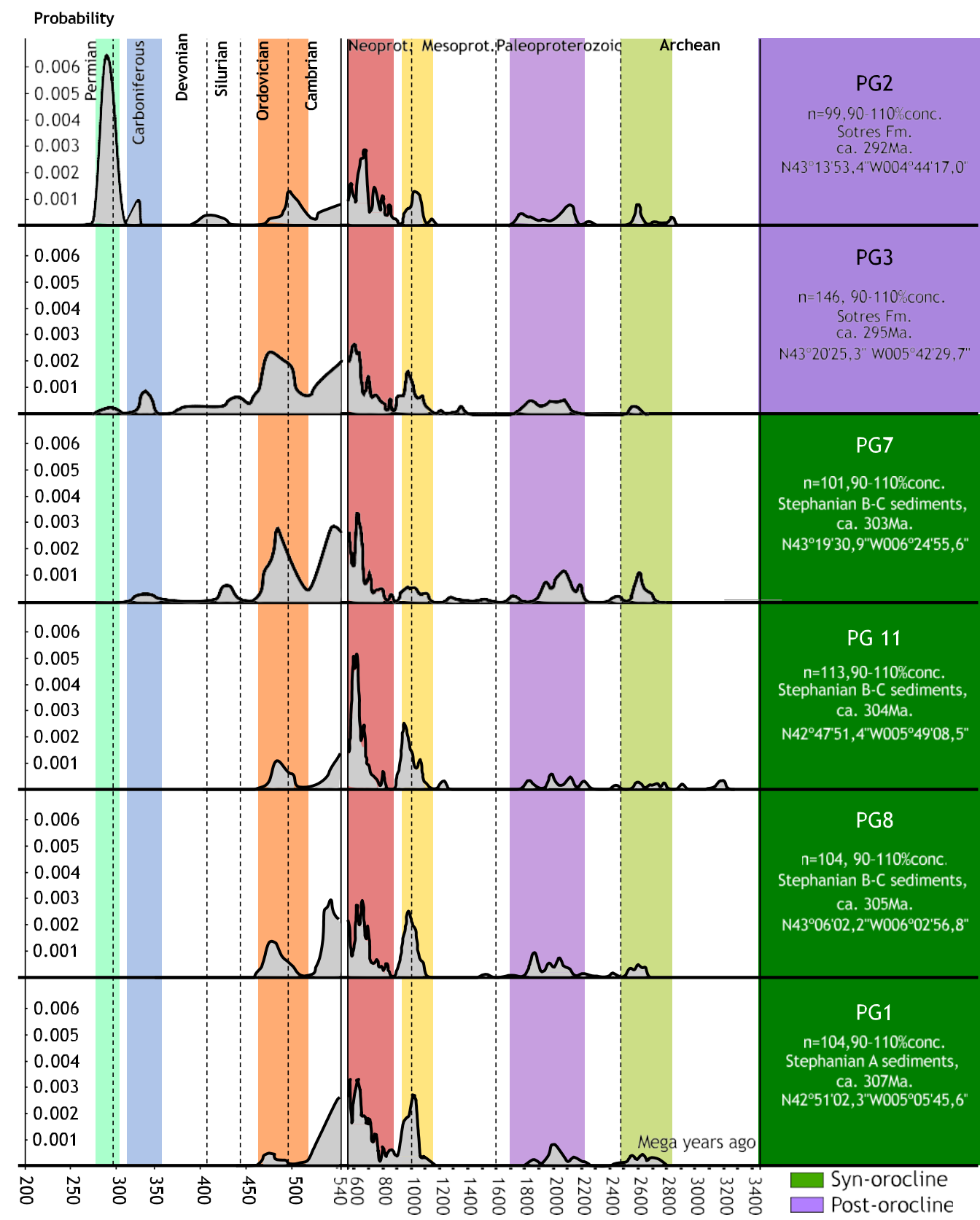

Fig. 7. Probability plots chronologically ordered from Upper Pennsylvanian to Early Permian. For details see Fig. 6 caption.

Carboniferous to Early Permian (310-290 Ma) population with a maximum at $300 \mathrm{Ma}$.

\section{Discussion}

\subsection{Zircon-forming events}

Many of the main populations (peaks) identified in the Kernel density diagram (Fig. 8) can be related to established different-zircon forming events. The Late Archean and Proterozoic populations are common features in many clastic sequences worldwide. For example, the 2800-2500 Ma population has been linked to global-scale orogenic events associated with the formation of a Late Archean supercontinent (known by different names, Vaalbara, Superia, Sclavia or Kenorland; Bradley, 2011 and references therein). In the surrounding areas have been commonly ascribed to being shred from the West African Craton (e.g. Díez Fernández et al., 2010; Avigad et al., 2012). Similarly, the
2150-1750 Ma population is coincident with the suggested time for the amalgamation of the supercontinent Nuna (Bradley, 2011). All the sam- ples contain more dominant populations that are coeval with Grenville orogenesis (900-1100 Ma; Evans, 2009), interpreted to be responsible of the formation of the supercontinent Rodinia and with the Cadomian-PanAfrican orogeny (850-540 Ma) which occurred within and along the northern margin of Gondwana (Figs. 6-9; Murphy et al., 2006).

The Late Cambrian-Early Ordovician population corresponds with widespread magmatic events along the northern margin (Amazonia, West Africa) of Gondwana associated with the opening of the Rheic Ocean. Examples of such magmatism in NW Iberia include the "Ollo de Sapo" volcano-sedimentary formation (Fig. 8; Díez-Montes, 2006).

The Mississippian zircon population corresponds with the tectonic exhumation and/or denudation of the orogenic igneous rocks developed during the Variscan Orogeny (e.g. Fernandez-Suarez et al., 2000). The 


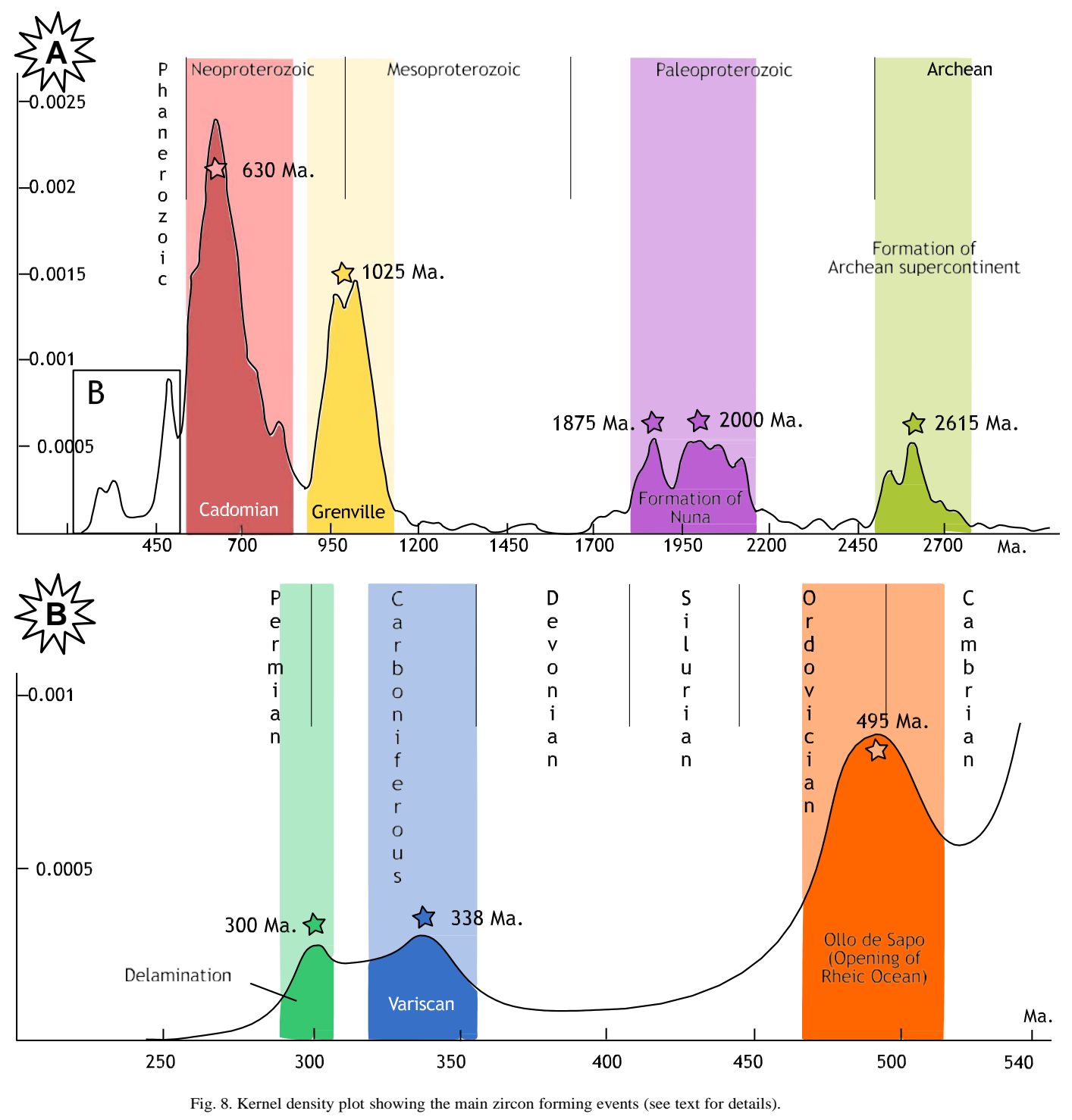

Late Carboniferous-Early Permian population is interpreted to reflect zircons formed during intra-crustal magmatism triggered by a thermal event produced by thinning (outer arc) and delamination (inner arc) of the lithospheric mantle as a consequence of oroclinal buckling in NW Iberia (Gutiérrez-Alonso et al., 2004, 2011a,b; Pastor-Galán et al., 2012b).

\subsection{Paleogeographic constraints of NW Iberia during the Paleozoic}

Previous U-Pb studies in detrital zircons of sedimentary rocks in NW Iberia have constrained the paleogeographic position and tectonic evolution of Iberia from Ediacaran to Ordovician times. Based on the match between detrital zircon populations and potential sources, these studies conclude that NW Iberia was located near northern Africa in the Ordovician (e.g. Fernández-Suárez et al., 2002; Bea et al., 2010; Díez Fernández et al., 2010). Our data yield similar populations in Silurian to Late Devonian strata, suggesting derivation from the same source. Collectively, these data are consistent with a long-lived (Lower Cambrian-Upper Devonian) passive margin setting that was not affect- ed by any significant zircon forming event, except for the extension re- lated to the rift-drift transition of the Avalonia terranes and the opening of the Rheic Ocean in lower Ordovician times (e.g. Murphy et al., 2006) and/or changes in the source areas. There is no evidence for the development of a magmatic arc during this time interval, indicating that closure of the Rheic Ocean could not have been accommodated by subduction beneath the Gondwanan margin (e.g. Stampfli and Borel, 2002; von Raumer and Stampfli, 2008). Instead, these data are consistent with the hypothesis of a northerly-directed subduction of the Rheic oceanic lithosphere beneath Laurussia (Arenas and Catalán, 2003; Nance et al., 2010 and references therein). These data also indicate that NW Iberia was part of the passive northern margin of Gondwana from the Late Cambrian-Early Ordovician opening of Rheic Ocean (e.g. Díez-Montes, 2006; Avigad et al., 2012; Fig. 10) until the onset of collision between Gondwana and Laurussia which began in the Late Devonian (e.g. Dallmeyer et al., 1997; Fig. 10).

The zircon populations of the CZ in the Late Cambrian-Late Devonian strata have approximately the same percentages of Proterozoic populations (ca. $30 \%$ of $850-540$ Ma zircons, ca. $30 \%$ of $1150-900$ Ma zir- cons and ca. $40 \%$ of 2150-1750 Ma zircons) and minor Archean zircons (Figs. 6-9). These populations are similar to those in detrital rocks of the same age in central north Africa, except for the slightly higher pro- portion of 1150-900 Ma zircons found in this study (25\%-30\% for this study and $20 \%-25 \%$ for central north Africa; 25\%-30\%) (Meinhold et al., 2011, 2012) but different to those in western north Africa (e.g. Abati et al., 2010; Avigad et al., 2012) and the eastern Mediterranean region (Avigad et al., 2003; Kolodner et al., 2006), which are devoid of 1150- 900 Ma zircons. The populations found in the CZ also match the presently known bedrocks in central north Africa during this interval of time: the Saharan Craton and Arabian-Nubian shield (e.g. Loizenbauer et al., 2001; Abdelsalam et al., 2002; Be'eri-Shlevin et al., 2009; Stern et 


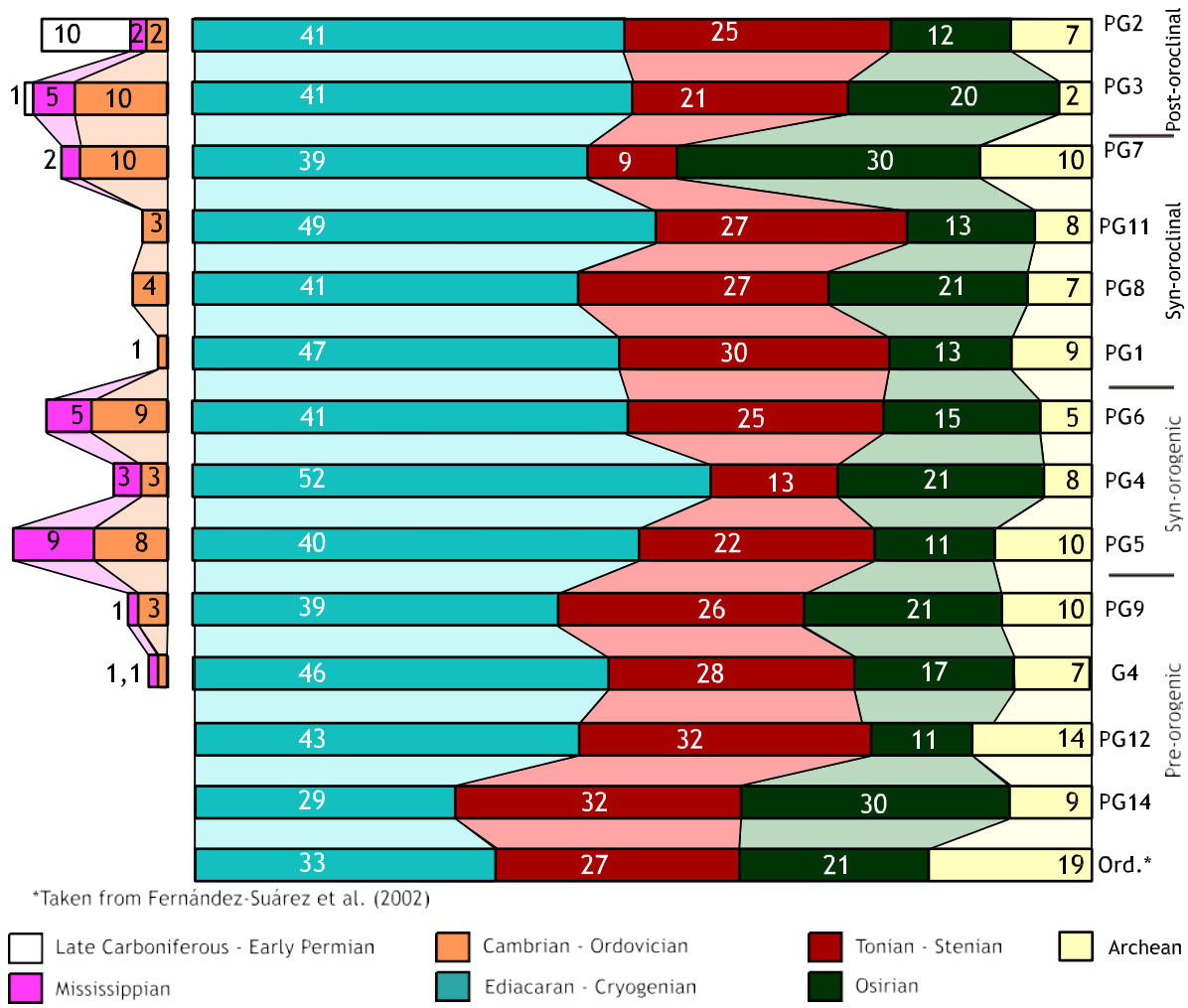

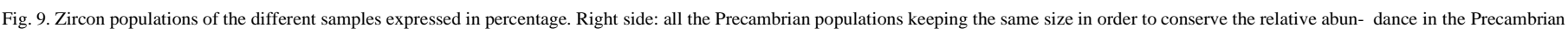
populations to allow the comparison between samples with and without Paleozoic zircons. Paleozoic populations represented on the left hand side of the figure.

al., 2010; Morag et al., 2011; Avigad et al., 2012). These data indicate that central north Africa is the nearest likely paleoposition for the CZ from at least the Ordovician to the Late Devonian.

\subsection{Changes in provenance during and after the Variscan orogeny}

The orogenic and post-orogenic kinematics in NW Iberia are well constrained (e.g. Dallmeyer et al., 1997; Alonso et al., 2009; Weil et al., 2010). In the hinterland of the orogen, the collision, deformation and magmatic events have been established through geochronological data (see references in the Introduction), whereas in the foreland the constraints derive from the ages of the synorogenic sequences or paleomagnetic data (Weil et al., 2001, 2010). All the time constraints provide a frame in which the different studied sediments can be placed in time and space within the progressive development of the Variscan orogen and its subsequent lithospheric scale oroclinal buckling. From this point of view, we have compiled Fig. 10 to provide a visual scenar- io where, based in the up-to-date knowledge of the lithospheric scale evolution of the NW Iberian Variscan belt, the different populations of zircons found through time in the $\mathrm{CZ}$ can be better understood.

In contrast to the stability of source regions from the Lower Ordovician to the Late Devonian, in the Carboniferous rocks two new zircon populations occur, one spanning from the Late Cambrian to Early Ordovician (510-475 Ma), the other is a Middle Devonian-Mississippian population (315-359 Ma). In addition some scarce Silurian zircons are also present. The Mississippian population is not present in three of the Stephanian samples (Figs. 7 and 9).

Compared to the passive margin pre-orogenic rocks, the syn-orogenic and synoroclinal Carboniferous clastic rocks contain a higher proportion of Neoproterozoic zircons (850-540 Ma, 52\% in sample PG4; Figs. 3 and 5) as well as a significant Cambrian-Ordovician (510-475 Ma) zircon population. These changes may reflect the exhumation of Neoproterozoic basement rocks of NW Iberia during Variscan deformation, a conclusion consistent with (i) regional syntheses indicating that the Variscan mountains started to form in the late Devonian (Fig. 10; Dallmeyer et al., 1997), and (ii) stratigraphic studies indicating that this interval was accompanied by a change from shelf to foreland basin deposition (Keller et al., 2008). The U-Pb zircon data suggest that the sediment supply involved the recycling of the previously old strata and erosion of igneous rocks formed during the Late Cambrian-Early Ordovician (opening of the Rheic Ocean) (Figs. 8 and 10; Murphy et al., 2008; Montes et al., 2010). In addition, the presence of Late Ordovician, Silurian and Devonian zircons (450-395 Ma) is interpreted to be the result of the erosion of rocks within the Rheic Ocean suture zone, where zircons of these ages occur (Fernandez-Suarez et al., 2002; Sánchez-Martínez et al., 2007) and are located nowadays at least ca. $300 \mathrm{~km}$ to the west (present day co- ordinates). A similar population is found in syn-orogenic rocks of the hinterland (Catalan et al., 2008) although it does not present 1100-900 Ma zircon population due to the strong local input of rocks that lack this population (Díez Fernández et al., 2010). This populations are also present in syn-orogenic basins of SW Iberia, fringing both sides of the Rheic suture, which are interpreted to derive from a fully eroded subduction related magmatic arc from the Rheic Ocean (Pereira et al., 2012). The Mississippian population (359-316 Ma) is attributed to the denudation or exhumation of the synorogenic Variscan igneous rocks (e.g. FernándezSuárez et al., 2000).

Syn-oroclinal rocks have zircon populations very similar to those found in the Neoproterozoic clastic rocks of NW Iberia (Fernández- Suárez et al., 2000). Compared with the pre-orogenic and the syn- orogenic strata, the synoroclinal rocks contain a lower proportion of Cambrian-Ordovician zircons, and lack of Silurian-Devonian or Mississippian zircons (with the exception of a $2 \%$ population in sample PG7, Figs. 7 and 9). These minor differences with pre-orogenic and syn-orogenic rocks are interpreted to reflect recycling of local strata, possibly facilitated by the uplift associated with coeval out-of-sequence thrusts (Alonso et al., 2009; Fig. 1B) and by reactivation of Variscan structures during oroclinal buckling 

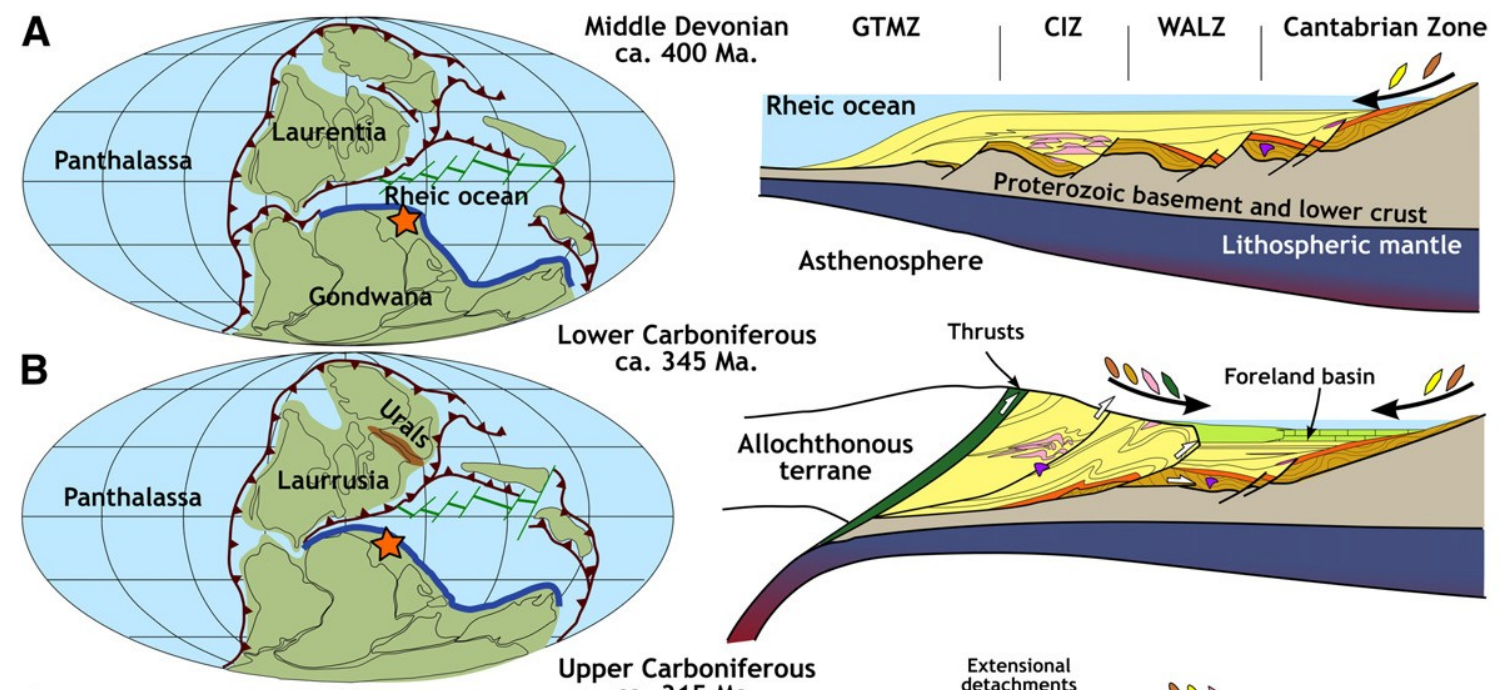

ca. $345 \mathrm{Ma}$.

C
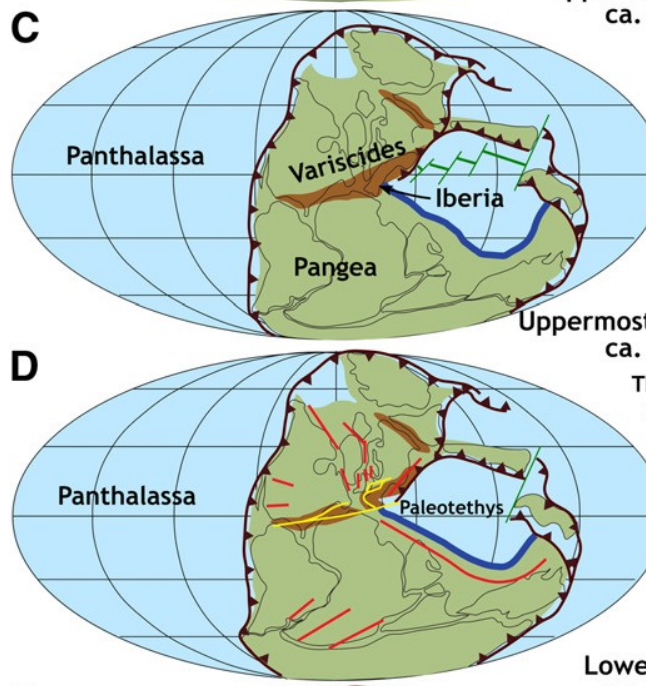

E

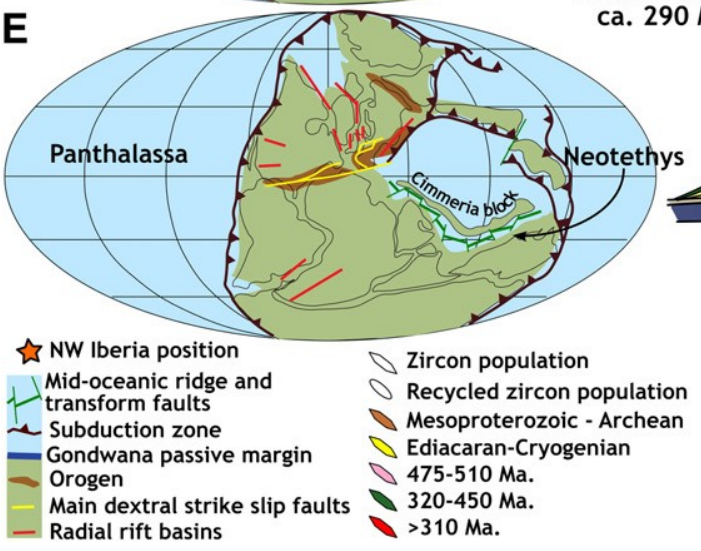

ca. $300 \mathrm{Ma}$.
Upper Carboniferous Extensional

ca. $315 \mathrm{Ma}$.
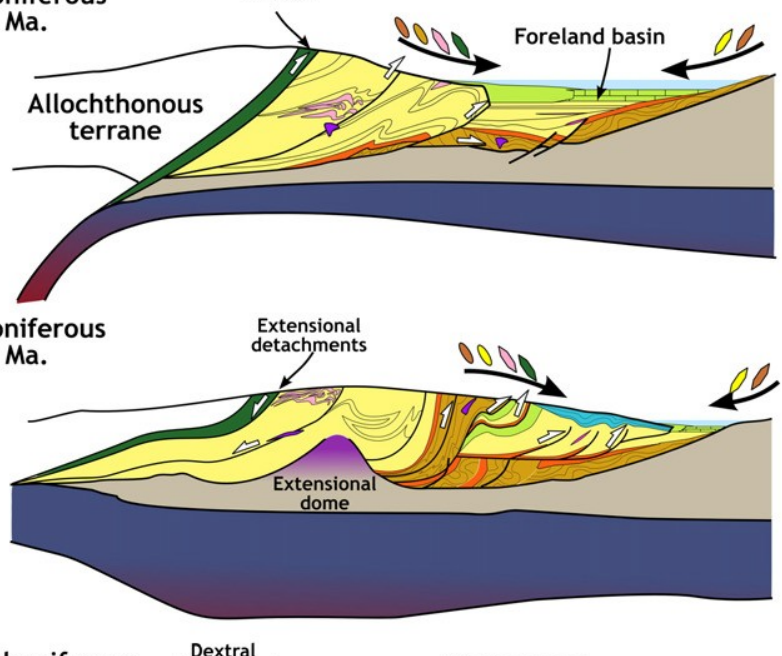

Dextral

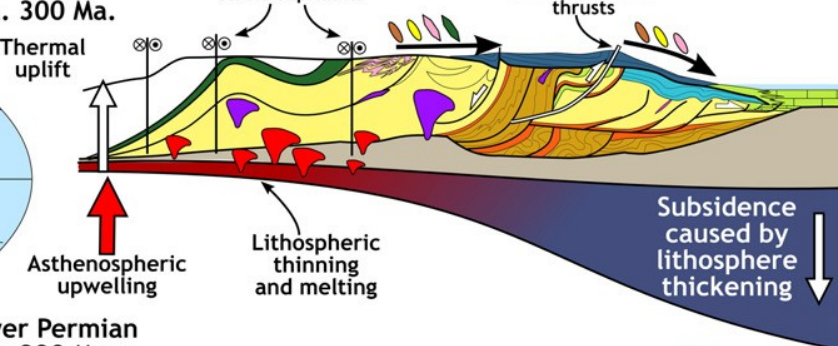

290 Ma.

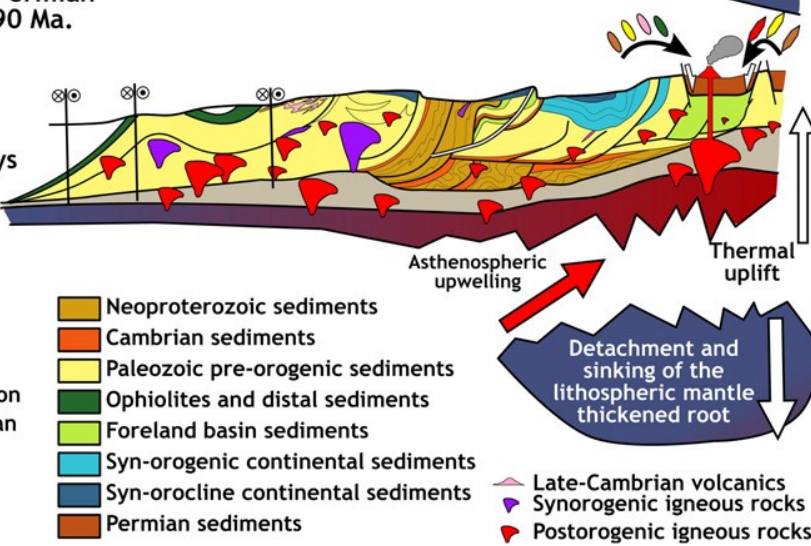

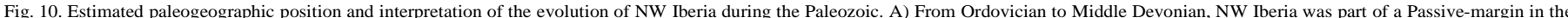

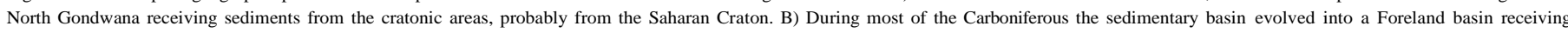

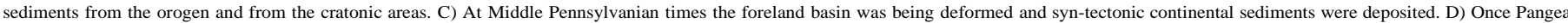

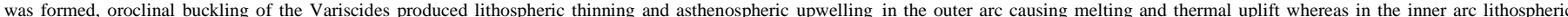

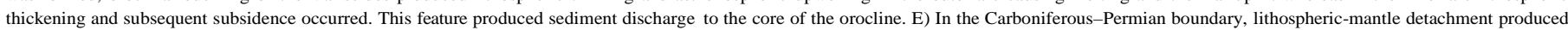
asthenospheric thermal uplift causing melting and thermal uplift. Grabens formed with local sedimentary sources from both sides.

(Pastor-Galán et al., 2012a; Weil et al., 2012). Samples PG1, PG11, and PG8 are located in strata that overlie Ordovician, Silurian, Devonian and Carboniferous rocks (Figs. 1B and 9) and contain similar populations to those of the pre-orogenic sedimentary rocks as well as a small input of Late Cambrian-Early Ordovician zircons (Figs. 6, 7 and 9). These detrital zircons may have been derived from the recycling of local pre- Pennsylvanian strata, in which the Mississippian zircon population is scarce or absent revealing a small input from the internal zones of the orogen. However, PG7 contains Cambrian-Ordovician and Mississippian populations in similar proportions to those of syn-orogenic foreland 
basin deposits of the CCB as well as a small 1150-900 Ma zircon popula- tion (Figs. 7 and 9). These differences may reflect its more westerly loca- tion in the CZ. The outcrop where PG7 was collected is located over Cambrian and Ediacaran rocks (Fig. 1B), thus during the uplift related with the oroclinal buckling the sedimentary basin was also possibly fed by recycling local Ediacaran and Cambrian strata and detritus from the hinterland.

Finally, the formation of the Permian basins and associated volcanism is attributed to isostatic uplift (Muñoz-Qujano and Gutiérrez-Alonso, 2007) caused by lithospheric delamination (Gutiérrez-Alonso et al., 2004, 2008, 2011a,b; Pastor-Galán et al., 2012b). Permian strata not only contain very similar zircon populations to the Carboniferous pre-orogenic and syn-orogenic strata, but also contain Early Permian zircons, attributed to erosion of the coeval Permian volcanic rocks interbedded with the siliciclastic strata. However, sample PG2, locat- ed furthest to the east, has only minor Cambrian-Ordovician and Mississippian populations (Figs. 7 and 9). The zircon populations of PG2 and PG3 can be explained by the recycling of pre-, syn and post-orogenic CZ strata to the west and the erosion of the presum- ably outcropping Gondwana basement to the east (in present day coordinates and not currently exposed). Therefore, outcrops situated to the east (in present-day coordinates) probably received a higher sediment input from Gondwanan basement rocks (PG2, Fig. 1B) whereas outcrops situated to the west (in present day coordinates) show more input from the recycling of the deformed pre-orogenic passive-margin rocks, as well as from the syn-orogenic foreland rocks(PG3, Fig.1B).

\section{Conclusions}

U-Pb geochronological analysis of detrital zircons in thirteen samples of the $\mathrm{CZ}$ (NW Iberia) of the Variscan belt reveals that it was part of the northern passivemargin of Gondwana from the Ordovician to Late De- vonian, until the collision between Gondwana and Laurussia. Zircon populations in these samples show important similarities with zir- cons found in coeval detrital rocks from central north Africa (Meinhold et al., 2011, 2013-this volume). Additionally, the populations found in NW Iberia are coherent with a Saharan source. We suggest that NW Iberia was situated from Ordovician to Late Devonian along the Gondwana northern passive margin close to the paleoposition of central north Africa and Saharan craton. Moreover, the Carboniferous-Permian samples, together with the geological constraints from the exhaustive knowledge of the Variscan and post-Variscan evolution of NW Iberia, re- cord the tectonic exhumation and/or the different topographic uplifts and denudation of the sediment sources produced along the Variscan oroge- ny, and the lithospheric scale Cantabrian Oroclineformation.

Detrital zircon studies can complement regional syntheses in deduc- ing paleogeographic locations, the occurrence of major tectonic events such as terrane dispersal and continental collisions, as well as to con- strain and interpret the crustal response to lithospheric-scale processes such as oroclinal buckling and the associated topographical uplift relat- ed to lithospheric delamination.

\section{Acknowledgments}

We would like to thank F. Pereira and D. Avigad for their construc- tive reviews that helped to improve this paper and J.R. Colmenero for his help taking samples. This is a contribution to IGCP 574 and IGCP

597. This work's financial support was supplied by Research Project ODRE II (“Oroclines and Delamination: Relations and Effects”) No. CGL2009-1367, from the Spanish Ministry of Science and Innovation and N.S.E.R.C., Canada. JFS wishes to acknowledge financial support from project CONSOLIDER CGL2007-65338-C02-01/BTE by the Spanish Ministry of Science and Technology.

\section{Appendix A. Supplementary data}

Supplementary data to this article can be found online at http:// dx.doi.org/10.1016/j.gr.2012.06.015.

\section{References}

Abati, J., Aghzer, A.M., Gerdes, A., Ennih, N., 2010. Detrital zircon ages of Neoproterozoic sequences of the Moroccan Anti-Atlas belt. Precambrian Research 181, 115-128.

Abdelsalam, M.G., Liégeois, J.-P., y Stern, R.J., 2002. The Saharan Metacraton. Journal of African Earth Sciences 34 (3-4), 119-136. http://dx.doi.org/10.1016/ S0899-5362(02)00013-1.

Alonso, J.L., 1987. Sequences of thrusts and displacement transfer in the superposed duplexes of the Esla Nappe region (Cantabrian Zone, NW Spain). Journal of Struc- tural Geology 9 (8), 969-983.

Alonso, J.L., 1989. Fold reactivation involving angular unconformable sequences- theoreticalanalysis and natural examples from the Cantabrian Zone (Northwest Spain). Tectonophysics $170(1-2), 57-77$

Alonso, J.L., Marcos, A., Suarez, A., 2009. Paleogeographic inversion resulting from large out of sequence breaching thrusts: the Leon Fault (Cantabrian Zone, NW Iberia). A new picture of the external Variscan Thrust Belt in the Ibero-Armorican Arc. Geologica Acta 7, 451the ext.

Alvarez-Marron, J., Perez-Estaun, A., 1988. Thin skinned tectonics in the Ponga region (Cantabrian Zone, NW Spain). Geol Rundsch 77, 539-550.

Aramburu, C., García-Ramos, J.C., 1993. La sedimentación cambro-ordovícica en la Zona Cantábrica (NO de España). Trabajos de Geología 19, 45-73.

Aramburu, C., Méndez-Bedia, I., Arbizu, M., 2002. The Lower Palaeozoic in the Cantabrian Zone (Cantabrian Mountains, NW Spain). In: García-López, S., Bastida, F. (Eds.), Paleozoic Conodonts from Northern Spain, Cuadernos Del Museo Geominero, pp. 35-49.

Arenas, R., Catalan, J.R.M., 2003. Low-P metamorphism following a Barrovian-type evolution. Complex tectonic controls for a common transition, as deduced in the Mondonedo thrust sheet (NW Iberian-Massif). Tectonophysics 365, 143-164.

Arenas, R., Catalan, J.R.M., Martinez, S.S., Fernandez-Suarez, J., Andonaegui, P., Pearce, J.A., Corfu, F., 2007. The Vila de Cruces ophiolite: a remnant of the early Rheic Ocean in the Variscan suture of Galicia (northwest Iberian Massif). Journal of Geology 115, 129-148.

Avigad, D., Kolodner, K., McWilliams, M., Persing, H., Weissbrod, T., 2003. Origin of northern Gondwana Cambrian sandstone revealed by detrital zircon SHRIMP dating. Geology 31, 227230.

Avigad, D., Gerdes, A., Morag, N., Bechstädt, T., 2012. Coupled U-Pb-Hf of detrital zircons of Cambrian sandstones from Morocco and Sardinia: implications for provenance and Precambrian crustal evolution of North Africa. Gondwana Research 21, 690-703.

Barreiro, J.G., Wijbrans, J.R., Castineiras, P., Catalan, J.R.M., Arenas, R., Garcia, F.D., Abati, J., 2006. Ar40/Ar-39 laserprobe dating of mylonitic fabrics in a polyorogenic terrane of NW Iberia. Journal of the Geological Society 163, 61-73.

Bastida, F., 2004. Zona Cantábrica. In: Vera, J.A. (Ed.), Geología De España. SGE-IGME, Madrid, pp. $25-49$.

Bastida, F., Blanco-Ferrera, S., Garcia-Lopez, S., Sanz-Lopez, J., Valin, M.L., 2004. Transi- tion from diagenesis to metamorphism in a calcareous tectonic unit of the Iberian Variscan belt (central massif of the Picos de Europa, NW Spain). Geological Magazine 141, 617-628.

Bea, F., Montero, P., Talavera, C., Abu Anbar, M., Scarrow, J.H., Molina, J.F., Moreno, J.A., 2010. The palaeogeographic position of Central Iberia in Gondwana during the Ordovician: ev- idence from zircon chronology and Nd isotopes. Terra Nova 22, 341-346.

Be'eri-Shlevin, Y., Katzir, Y., Whitehouse, M.J., y Kleinhanns, I.C., 2009. Contribution of pre PanAfrican crust to formation of the Arabian Nubian Shield: new secondary ionization mass spectrometry $\mathrm{U}-\mathrm{Pb}$ and $\mathrm{O}$ studies of zircon. Geology 37 (10), 899-902. http://dx.doi.org/10.1130/G30206A.1.

Bradley, D.C., 2011. Secular trends in the geologic record and the supercontinent cycle. Earth-Science Reviews $108 \quad(1-2), \quad 16-33 . \quad$ http://dx.doi.org/10.1016/ j.earscirev.2011.05.003.

Brime, C., Garcia-Lopez, S., Bastida, F., Valin, M.L., Sanz-Lopez, J., Aller, J., 2001. Transi- tion from diagenesis to metamorphism near the front of the Variscan regional metamorphism (Cantabrian Zone, northwestern Spain). Journal of Geology 109, 363-379.

Catalan, J.R.M., Fernandez-Suarez, J., Jenner, G.A., Belousova, E., Montes, A.D., 2004. Provenance constraints from detrital zircon U-Pb ages in the NW Iberian Massif: implications for Palaeozoic plate configuration and Variscan evolution. Journal of the Geological Society 161, 463-476.

Catalan, J.R.M., Fernandez-Suarez, J., Meireles, C., Clavijo, E.G., Belousova, E., Saeed, A., 2008. U-Pb detrital zircon ages in synorogenic deposits of the NW Iberian Massif (Variscan belt): interplay of Devonian-Carboniferous sedimentation and thrust tectonics. Journal of the Geological Society 165, 687-698.

Colmenero, J.R., Prado, J.G., 1993. Coal basins in the Cantabrian Mountains, northwestern Spain. International Journal of Coal Geology 23, 215-229.

Colmenero, J., Suarezruiz, I., Fernandezsuarez, J., Barba, P., Llorens, T., 2008. Genesis and rank distribution of Upper Carboniferous coal basins in the Cantabrian Mountains, Northern Spain. International Journal of Coal Geology 76, 187-204.

Corrales, I., 1971. La sedimentación durante el Estefaniense B-C en Cangas de Narcea, Rengos y Villablino (NW de España). Trabajos de Geología 3, 69-73.

Dallmeyer, R.D., Catalan, J.R.M., Arenas, R., Ibarguchi, J.I.G., Alonso, G.G., Farias, P., Bastida, F., Aller, J., 1997. Diachronous Variscan tectonothermal activity in the NW Iberian 
Massif: evidence from Ar-40/Ar-39 dating of regional fabrics. Tectonophysics 277, 307-337. Díez Fernández, R., Catalán, J.R.M., Gerdes, A., Abati, J., Arenas, R., Fernández-Suárez, J., 2010. U-Pb ages of detrital zircons from the Basal allochthonous units of NW Iberia: provenance and paleoposition on the northern margin of Gondwana during the Neoproterozoic and Paleozoic. Gondwana Research 18, 385-399.

Díez-Montes, A., 2006. La Geología del Dominio “Ollo de Sapo” en las comarcas de Sanabria y Terra do Bolo ( $\mathrm{PhD}$ Thesis).

Evans, D.A.D., 2009. The paleomagnetically viable, long-lived and all-inclusive Rodinia supercontinent reconstruction. Geological Society, London, Special Publication 327, 371404

Fernandez-Suarez, J., Gutierrez-Alonso, G., Jenner, G.A., Tubrett, M.N., 1999. Crustal sources in Lower Palaeozoic rocks from NW Iberia: insights from laser ablation U-Pb ages of detrital zircons. Journal of the Geological Society 156, 1065-1068.

Fernández-Suárez, J., Dunning, G.R., Jenner, G.A., Gutiérrez-Alonso, G., 2000. Variscan collisional magmatism and deformation in NW Iberia: constraints from U-Pb geo- chronology of granitoids. Journal of the Geological Society 157, 565-576.

Fernandez-Suarez, J., Gutierrez-Alonso, G., Jenner, G.A., Tubrett, M.N., 2000. New ideas on the Proterozoic-Early Palaeozoic evolution of NW Iberia: insights from U-Pb detrital zircon ages. Precambrian Research 102, 185-206.

Fernández-Suárez, J., Alonso, G.G., Cox, R., Jenner, G.A., 2002. Assembly of the Armorica microplate: a strike-slip terrane delivery? Evidence from U-Pb ages of detrital zircons. Journal of Geology 110, 619-626.

Fernandez-Suarez, J., Corfu, F., Arenas, R., Marcos, A., Catalan, J.R.M., Garcia, F.D., Abati, J., Fernandez, F.J., 2002. U-Pb evidence for a polyorogenic evolution of the HP-HT units of the NW Iberian Massif. Contributions to Mineralogy and Petrology 143, 236-253.

Fernandez-Suarez, J., Arenas, R., Jeffries, T.E., Whitehouse, M.J., Villaseca, C., 2006. A U-Pb study of zircons from a lower crustal granulite xenolith of the Spanish central system: a record of lberian lithospheric evolution from the Neoproterozoic to the Triassic. Jour- nal of Geology 114, 471-483.

Fernández-Suárez, J., Gutierrez-Alonso, G., Johnston, S.T., Jeffries, T.E., Pastor-Galán, D., Jenner, G.A., Murphy, J.B., 2011. Iberian late-Variscan granitoids: some considerations on crustal sources and the significance of "mantle extraction ages". Lithos 123, 121-132.

Frei, D., Gerdes, A., 2009. Precise and accurate in situ U-Pb dating of zircon with high sample throughput by automated LA-SF-ICP-MS. Chemical Geology 261, 261-270. García-López, S.

Brime, C., Valín, M.L., Sanz-López, J., Bastida, F., Aller, J.,Blanco-Ferrera, S., 2007. Tectonothermal evolution of a foreland fold and thrust belt: the Cantabrian Zone (Iberian Variscan belt, NW Spain). Terra Nova 19, 469-475.

Gasparrini, M., Bechstadt, T., Boni, M., 2006. Massive hydrothermal dolomites in the southwestern Cantabrian Zone (Spain) and their relation to the Late Variscan evo- lution. Marine and Petroleum Geology 23, 543-568.

Gibbons, W., Moreno, T., D., T.M. Ph., 2002. The geology of Spain. Geological Society. Gradstein,

F.M., Ogg, J.G., Smith, A.G., 2004. A Geologic Time Scale 2004. Cambridge University Press, Cambridge.

Gutiérrez-Alonso, G., 1996. Strain partitioning in the footwall of the Somiedo Nappe: structural evolution of the Narcea Tectonic window, NW Spain. Journal of Structural Geology 18, 1217 1229.

Gutierrez-Alonso, G., Nieto, F., 1996. White-mica “crystallinity", finite strain and cleavage development across a large Variscan structure, NW Spain. Journal of the Geological Society 153, 287-299.

Gutierrez-Alonso, G., Fernandez-Suarez, J., Jeffries, T., et al., 2003. Terrane accretion and dispersal in the northern Gondwana margin. An early paleozoic analogue of a long- lived active margin. Tectonophysics 365, 221-232.

Gutiérrez-Alonso, G., Fernández-Suárez, J., Weil, A.B., 2004. Orocline triggered lithospheric delamination In: Weil, A.B., Sussman, A. (Eds.), Paleomagnetic and Structural Analysis of Orogenic Curvature, Special Paper. Geological Society of America, Boulder, pp. 121-131.

Gutiérrez-Alonso, G., Fernández-Suárez, J., Carlos Gutiérrez-Marco, J., Corfu, F., Murphy, J.B., Suárez, M., 2007. U-Pb depositional age for the upper Barrios For- mation (Armorican Quartzite facies) in the Cantabrian zone of Iberia: implica- tions for stratigraphic correlation and paleogeography. Geological Society of America Special Papers 423, 287-296.

Gutiérrez-Alonso, G., Fernandez-Suarez, J., Weil, A.B., Murphy, J.B., Nance, R.D., Corfu, F., Johnston, S.T., 2008. Self-subduction of the Pangaean global plate. Nature Geoscience 1, 549-553.

Gutiérrez-Alonso, G., Fernández-Suárez, J., Jeffries, T., Collins, A.S., Johnston, S.T., González- Clavijo, E., Pastor-Galán, D., 2010. Delimitação mediante idades absolutas $\left({ }^{40} \mathrm{Ar}{ }^{*}-{ }^{39} \mathrm{Ar}\right.$ e U-Pb) do desenvolvimento oroclinal e da delaminação litosférica associada no Arco Ibero Armoricano. Revista Electrónica de Ciências da Terra, pp. 23-24.

Gutiérrez-Alonso, G., Fernández-Suárez, J., Jeffries, T.E., Johnston, S.T., Pastor-Galán, D., Murphy, J.B., Franco, M.P., Gonzalo, J.C., 2011a. Diachronous post-orogenic magmatism within a developing orocline in Iberia, European Variscides. Tectonics 30 (17 pp.).

Gutiérrez-Alonso, G., Murphy, J.B., Fernández-Suárez, J., Weil, A.B., Franco, M.P., Gonzalo, J.C., 2011b. Lithospheric delamination in the core of Pangea: Sm-Nd insights from the Iberian mantle. Geology 39, 155-159. http://dx.doi.org/10.1130/G31468.1.

Gutiérrez-Alonso, G., Johnston, S.T., Weil, A.B., Pastor-Galán, D., Fernández-Suárez, J., 2012. Buckling an orogen: the Cantabrian Orocline. GSA Today 22, 4-9.

Heckel, P.H., Clayton, G., 2006. The Carboniferous system: use of the new official names for the subsystems, series, and stages. Geologica Acta 4 (3), 403-407.

Johnston, S.T., y Gutiérrez-Alonso, G., 2010. The North American Cordillera and West European Variscides: contrasting interpretations of similar mountain systems. Gondwana Research 17, 516-525. http://dx.doi.org/10.1016/j.gr.2009.11.006.

Julivert, M., Arboleya, M.L., 1986. Areal balancing and estimate of areal reduction in a thin-skinned fold-and-thrust belt (Cantabrian Zone, NW Spain) - constraints on its emplacement mechanism. Journal of Structural Geology 8, 407-414.
Julivert, M., Marcos, A., 1973. Superimposed folding under flexural conditions in the Cantabrian Zone (Hercynian Cordillera, northwest Spain). Am J Sci 273, 353-375.

Keller, M., Bahlburg, H., Reuther, C.D., 2008. The transition from passive to active margin sed- imentation in the Cantabrian Mountains, Northern Spain: Devonian or Carboniferous? Tectonophysics 461, 414 427.

Kolodner, K., Avigad, D., Mcwilliams, M., Wooden, J.L., Weissbrod, T., Feinstein, S., 2006. Provenance of north Gondwana Cambrian-Ordovician sandstone: U-Pb SHRIMP dating of detrital zircons from Israel and Jordan. Geological Magazine 143, 367-391.

Linnemann, U., McNaughton, N.J., Romer, R.L., Gehmlich, M., Drost, K., Tonk, C., 2004. West African provenance for Saxo-Thuringia (Bohemian Massif): did Armorica ever leave pre-Pangean Gondwana? U/Pb-SHRIMP zircon evidence and the Nd-isotopic record. International Journal of Earth Sciences 93, 683-705.

Linnemann, U., Pereira, F., Jeffries, T.E., Drost, K., Gerdes, A., 2008. The Cadomian Orogeny and the opening of the Rheic Ocean: the diacrony of geotectonic processes constrained by LA-ICP-MS U-Pb zircon dating (Ossa-Morena and Saxo-Thuringian Zones, Iberian and Bohemian Massifs). Tectonophysics 461, 21-43.

Loizenbauer, J., Wallbrecher, E., Fritz, H., Neumayr, P., Khudeir, A., y Kloetzli, U., 2001. Structura geology, single zircon ages and fluid inclusion studies of the Meatiq metamorphic core complex. Implications for Neoproterozoic tectonics in the East- ern Desert of Egypt. Precambrian Research 110 (1-4), 357-383. http://dx.doi.org/ 10.1016/S03019268(01)00176-0.

Lonergan, L., Johnson, C., 1998. Reconstructing orogenic exhumation histories using synorogenic detrital zircons and apatites: an example from the Betic Cordillera, SE Spain. Basin Research 10, 353-364.

Ludwig, K.R., 1998. On the treatment of concordant uranium-lead ages. Geochimica et Cosmochimica Acta 62, 665-676.

Ludwig, K.R., 2001. SQUID 1.02, a User's Manual. Special Publication, 2. Berkeley Geochronol- ogy Center. $17 \mathrm{pp}$.

Martínez Catalán, J.R., Arenas, R., Abati, J., Sánchez-Martínez, S., Díaz-García, F., Fernández-Suárez, J., González Cuadra, P., Castiñeiras, P., Gómez-Barreiro, J., Díez Montes, A. González Clavijo, E., Rubio Pascual, F.J., Andonaegui, P., Jeffries, T.E., Alcock, J.E., Díez Fernández, R., López-Carmona, A., 2009. A rootless suture and the loss of the roots of a mountain chain: the Variscan Belt of NW Iberia. Comptes Rendus Geoscience. 341 (2-3), 114-126.

Martinez, F.J., Reche, J., Iriondo, A., 2008. U-Pb Shrimp-RG zircon ages of Variscan igneous rocks from the Guilleries massif (NE Iberia pre-Mesozoic basement). Geological im- plications. Comptes Rendus Geoscience 340, 223-232.

Martínez-García, E., 1981. El Paleozoico de la Zona Cantábrica Oriental (Noroeste de España). Trabajos de Geología 11, 95-127.

Martínez-García, E., 1991. Hercynian synorogenic and postorogenic sucessions in the Cantabrian and Palentian Zobes, NW Spain. Comparisons with other western European ocurrences. Giornale di Geologia 53, 209-228.

Martin-Izard, A., Fuertes-Fuente, M., Cepedal, A., Moreiras, D., Nieto, J.G., Maldonado, C., Pevida, L.R., 2000. The Rio Narcea gold belt intrusions: geology, petrology, geo- chemistry and timing. Journal of Geochemical Exploration 71, 103-117.

Meinhold, G., Morton, A.C., Fanning, C.M., Frei, D., Howard, J.P., Phillips, R.J., Strogen, D., Whitham, A.G., 2011. Evidence from detrital zircons for recycling of Mesoproterozoic and Neoproterozoi crust recorded in Paleozoic and Mesozoic sandstones of southern Libya. Earth and Planetary Science Letters 312, 164-175.

Meinhold, G., Morton, A.C., Avigad, D., 2013. New insights into peri-Gondwana paleo- geography and the Gondwana super-fan system from detrital zircon U-Pb ages. Gondwana Research 23, 661-665 (this volume).

Montes, A.D., Catalán, J.R.M., Mulas, F.B., 2010. Role of the Ollo de Sapo massive felsic volcanism of NW Iberia in the Early Ordovician dynamics of northern Gondwana. Gondwana Research 17, 363-376.

Morag, N., Avigad, D., Gerdes, A., Belousova, E., y Harlavan, Y., 2011. Detrital zircon Hf isotopic composition indicates long-distance transport of North Gondwana Cambrian-Ordovician sandstones. Geology 39 (10), 955-958. http://dx.doi.org/ 10.1130/G32184.1.

Muñoz-Quijano, I.N., Gutiérrez-Alonso, G., 2007. Respuesta topográfica a un proceso de delaminación litosférica: un modelo simple para el final del Orógeno Varisco en el NO de la Península Ibérica. Studia Geologica Salmanticensia 43, 175-192.

Murphy, J.B., Strachan, R.A., Nance, R.D., Parker, K.D., Fowler, M.B., 2000. Prota-Avalonia: a 1.2-1.0 Ga tectonothermal event and constraints for the evolution of Rodinia. Geology 28, 1071-1074.

Murphy, J.B., Gutierrez-Alonso, G., Nance, R.D., Fernandez-Suarez, J., Keppie, J.D., Quesada, C., Strachan, R.A. Dostal, J., 2006. Origin of the Rheic Ocean: rifting along a Neoproterozoic suture? Geology 34, 325328.

Murphy, J.B., Dostal, J., Keppie, J.D., 2008. Neoproterozoic-Early Devonian magmatism in the Antigonish Highlands, Avalon terrane, Nova Scotia: tracking the evolution of the mantle and crustal sources during the evolution of the Rheic Ocean. Tectonophysics 461, 181-201.

Nance, R.D., Linnemann, U., 2008. The Rheic Ocean: origin, evolution, and significance. GSA Today 18,4

Nance, R.D., Gutiérrez-Alonso, G., Keppie, J.D., Linnemann, U., Murphy, J.B., Quesada, C., Strachan, R.A., Woodcock, N.H., 2010. Evolution of the Rheic Ocean. Gondwana Re- search 17, 194222.

Nie, J., Horton, B.K., Mora, A., Saylor, J.E., Housh, T.B., Rubiano, J., Naranjo, J., 2010. Tracking exhumation of Andean ranges bounding the Middle Magdalena Valley Basin, Colombia. Geology 38, 451-454.

Pastor-Galán, D., Gutiérrez-Alonso, G., Meere, P.A., Mulchrone, K.F., 2009. Factors af- fecting finite strain estimation in low-grade, low-strain clastic rocks. Journal of Structural Geology 31 (12), 586-1596.

Pastor-Galán, D., Gutiérrez-Alonso, G., Weil, A.B., 2011. Orocline timing through joint analysis: insights from the Ibero-Armorican Arc. Tectonophysics 507, 31-46. 
Pastor-Galán, D., Gutiérrez-Alonso, G., Mulchrone, K.F., Huerta, P., 2012a. Conical folding in the core of an orocline. A geometric analysis from the Cantabrian Arc (Variscan Belt of NW Iberia). Journal of Structural Geology 39, 210-223.

Pastor-Galán, D., Gutiérrez-Alonso, G., Zulauf, G., Zanella, F., 2012b. Analogue modeling of lithospheric-scale orocline buckling: constraints on the evolution of the Iberian- Armorican Arc. Geological Society of America Bulletin. http://dx.doi.org/10.1130/ B30640.1.

Pereira, M.F., Linnemann, U., Hofmann, M., Chichorro, M., Solá, A.R., Medina, J., Silva, J.B., 2012 The provenance of Late Ediacaran and Early Ordovician siliciclastic rocks in the Southwest Central Iberian Zone: constraints from detrital zircon data on northern Gondwana margin evolution during the late Neoproterozoic. Precambrian Re- search 192-195, 166-189.

Pereira, M.F., Solá, A.R., Chichorro, M., Lopes, L., Gerdes, A., Silva, J.B., 2012. North- Gondwana assembly, break-up and paleogeography: U-Pb isotope evidence from detrital and igneous zircons of Ediacaran and Cambrian rocks of SW Iberia. Gondwana Research 22, 866-881.

Pérez-Estaún, A., Bastida, F., Alonso, J.L., Marquinez, J., Aller, J., Alvarezmarron, J., Marcos, A., Pulgar, J.A., 1988. A thin-skinned tectonics model for an arcuate fold and thrust belt — the Cantabrian Zone (Variscan Ibero-Armorican Arc). Tectonics 7, 517-537.

Perez-Estaun, A., Pulgar, J.A., Banda, E., Alvarezmarron, J., Marcos, A., Bastida, F., Alonso, J.L., Aller, J., Farias, P., Martinezcatalan, J.R., Comas, M.C., Danobeitia, J.J., Cordoba, D., 1994. Crustal structure of the external variscides in northwest Spain from deep seismic-reflection profiling. Tectonophysics 232, 91-118.

Robardet, M., 2003. The Armorica "microplate": fact or fiction? Critical review of the concept and contradictory palaeobiogeographical data. Palaeogeography, Palaeoclimatology, Palaeoecology 195, 125-148.

Sanchez-Garcia, T., Quesada, C., Bellido, F., Dunning, G.R., del Tanago, J.G., 2008. Two- step magma flooding of the upper crust during rifting: the Early Paleozoic of the Ossa Moren Zone (SW Iberia). Tectonophysics 461, 72-90.

Sánchez-Martínez, S., Arenas, R., García, F.D., Martínez-Catalán, J.R., Gómez-Barreiro, J., y Pearce, J.A., 2007. Careon ophiolite, NW Spain: suprasubduction zone setting for the youngest Rheic Ocean floor. Geology 35 (1), 53-56.

Shaw, J., Johnston, S.T., Gutiérrez-Alonso, G., Weil, A.B., 2012. Oroclines of the Variscan orogen of Iberia: paleocurrent analysis and paleogeographic implications. Earth and Planetary Science Letters 329-330, 60-70. http://dx.doi.org/10.1016/ j.epsl.2012.02.014.

Sircombe, K.N., Hazelton, M.L., 2004. Comparison of detrital zircon age distributions by kernel functional estimation. Sedimentary Geology 171, 91-111.

Stacey, J.S., Kramers, J.D., 1975. Approximation of terrestrial lead isotope evolution by a two-stage model. Earth and Planetary Science Letters 26 (2), 207-221. http:// dx.doi.org/10.1016/0012-821X(75)90088-6.

Stampfli, G.M., Borel, G.D., 2002. A plate tectonic model for the Paleozoic and Mesozoic constrained by dynamic plate boundaries and restored synthetic oceanic isochrons. Earth and Planetary Science Letters 196, 17-33.

Stern, R.J., Ali, K.A., Liégeois, J.P., Johnson, P.R., Kozdroj, W., y Kattan, F.H., 2010. Distri- bution and significance of pre-Neoproterozoic zircons in juvenile Neoproterozoic igneous rocks of the Arabian-Nubian Shield. American Journal of Science 310 (9), 791-811. http://dx.doi.org/10.2475/09.2010.02.

Stewart, R.J., Hallet, B., Zeitler, P.K., Malloy, M.A., Allen, C.M., Trippett, D., 2008. Brahmaputra sediment flux dominated by highly localized rapid erosion from the easternmost Himalaya. Geology 36, 711-
Suárez, A., 1988. Estructura del área de Villaviciosa-Libardón (Asturias, Cordillera Cantábrica). Trabajos de Geología 17, 87-98.

Tait, J., 1999. New Early Devonian paleomagnetic data from NW France: paleogeography and implications for the Armorican microplate hypothesis. J. Geophys. Res. 104, 2831-2839.

Tait, J., Bachtadse, V., Soffel, H., 1994. New palaeomagnetic constraints on the position of central Bohemia during Early Ordovician times. Geophysical Journal International 116, 131-140.

Valverde-Vaquero, P., Díez Balda, M.A., Díez Montes, A., Dörr, W., Escuder Viruete, J., González Clavijo, E., Maluski, H., Rodríguez-Fernández, L.R., Rubio, F., Villar, P., 2006. Timing of Variscan metamorphism and the Central Iberian paradox. Geo- physical Research Abstracts, European Geosciences Union 8, 1.

van Der Voo, R., 1982. Pre-Mesozoic paleomagnetism and plate tectonics. Annual Re- view of Earth and Planetary Sciences 10, 191-220.

van Der Voo, R., 1988. Paleozoic paleogeography of North America, Gondwana, and inter- vening displaced terranes: comparisons of paleomagnetism with paleoclimatology and biogeographical patterns. Geological Society of America Bulletin 100, 311-324.

van der Voo, R., 1993. Paleomagnetism of the Atlantic, Tethys and Iapetus Oceans. Cambridge University Press, Cambridge.

Vermeesch, P., 2012. On the visualisation of detrital age distributions. Chemical Geology 312-313, 190-194.

von Raumer, J.F., Stampfli, G.M., 2008. The birth of the Rheic Ocean - Early Palaeozoic subsidence patterns and subsequent tectonic plate scenarios. Tectonophysics 461, 9-20.

Wand, M.P., Jones, M.C., 1995. Kernel Smothing. Chapman and Hall.

Weil, A.B., 2006. Kinematics of orocline tightening in the core of an arc: paleomagnetic analysis of the Ponga Unit, Cantabrian Arc, northern Spain. Tectonics 25.

Weil, A.B., van der Voo, R., 2002. Insights into the mechanism for orogen-related car- bonate remagnetization from growth of authigenic Fe-oxide: a scanning electron microscopy and rock magnetic study of Devonian carbonates from northern Spain. Journal of Geophysical Research-Solid Earth 107, 14.

Weil, A.B., van der Voo, R., van der Pluijm, B.A., 2001. Oroclinal bending and evidence against the Pangea megashear: the Cantabria-Asturias arc (northern Spain). Geology 29, 991-994.

Weil, A.B., Gutiérrez-Alonso, G., Conan, J., 2010. New time constraints on lithospheric- scale oroclinal bending of the Ibero-Armorican Arc: a paleomagnetic study of ear- liest Permian rocks from Iberia. Journal of the Geological Society, London 167, 17. Weil, A.B., Gutiérrez-Alonso, G., Wicks, D., 2012. Investigating the kinematics of local thrust sheet rotation in the limb of an orocline: a paleomagnetic and structural analysis of the Esla Tectonic Unit, Cantabrian-Asturian Arc NW Iberia. International Journal of Earth Sciences. http://dx.doi.org/10.1007/s00531-012-0790-3.

Weislogel, A.L., Graham, S.A., Chang, E.Z., Wooden, J.L., y Gehrels, G.E., 2010. Detrital zircon provenance from three turbidite depocenters of the Middle-Upper Triassic Songpan-Ganzi complex, central China: record of collisional tectonics, erosional exhumation, and sediment production. Geological Society of America Bulletin 122 (11-12), 2041-2062. http://dx.doi.org/10.1130/B26606.1. 